\title{
Sustainability and Optimization: From Conceptual Fundamentals to Applications
}

\author{
Ali Sadollah ${ }^{1}$, Mohammad Nasir ${ }^{2}$ and Zong Woo Geem ${ }^{3, * *(1)}$ \\ 1 Department of Mechanical Engineering, University of Science and Culture, Tehran, Iran; sadollah@usc.ac.ir \\ 2 Research Department of Energy, Materials and Energy Research Center, Karaj, Iran; m.nasir@iaud.ac.ir \\ 3 Department of Energy IT, Gachon University, Seongnam 13120, Korea \\ * Correspondence: geem@gachon.ac.kr
}

Received: 13 January 2020; Accepted: 2 March 2020; Published: 6 March 2020

\begin{abstract}
In recent years, both sustainability and optimization concepts have become inseparable developing topics with diverse concepts, elements, and aspects. The principal goal of optimization is to improve the overall sustainability including the environmental sustainability, social sustainability, economic sustainability, and energy resources sustainability through satisfying the objective functions. Therefore, applying optimization algorithms and methods to achieve the sustainable development have significant importance. This paper represents a considerable review on the employed optimization methodologies to sustainability and the sustainable development including sustainable energy, sustainable buildings, and sustainable environment. Since energy optimization is one of the major necessities of sustainability, sustainable development is investigated from the energy perspective. In addition, the concept, definitions, and elements of the sustainability and optimization have been presented, and the review of the optimization metaheuristic algorithms used in recent published articles related to sustainability and sustainable development was carried out. Thus, it is believed that this paper can be appropriate, beneficial, and practical for students, academic researchers, engineers, and other professionals.
\end{abstract}

Keywords: metaheuristics; optimization algorithms; sustainable development; sustainable energy resources; sustainable buildings

\section{Introduction}

With the publication of the Brundtland Report "Our Common Future," the concept of sustainable development has spread since 1987 [1]. The definition of the United Nations Brundtland Commission on sustainability has become more dynamic than others. We call sustainability the technology that meets today's needs without jeopardizing the future generations' ability to meet their own needs. Therefore, sustainability is a multidisciplinary concept, based on this understanding that covers different aspects of life. Clearly, sustainability is a concept in the core of the planet that focuses on the condition and depletion of the biophysical environment of Earth [2,3]. In 2015, the General Assembly adopted the 2030 Agenda for sustainable development. They adopted the Agenda for its action to combat poverty, protect the planet, and enhance everybody's lives and opportunities. This paper focuses on reviewing trends and recent research papers in sustainability and energy efficiency (i.e., Goals 7 and 12) and sustainable building design (i.e., Goals 11 and 15) problems out of 17 sustainable development goals.

Optimization is one of the most important tools for achieving sustainability. Optimization is a search process for a specific problem according to special conditions of that problem. In fact, optimization refers to finding processes of optimal values for a given network parameter, using all feasible values for the minimization or maximization of network output. The goal of optimization is to 
discover the best feasible response with the consideration of the problem constraints. The presence of complex scientific and engineering problems calls for using optimization methods to solve the desired problem. Due to the time consuming and complexity of exact methods, utilizing intelligent optimization algorithms has crucial importance.

Optimization of many complex scientific problems which require solutions with accurate computations and appropriate time cannot use classical methodologies. In this regard, nature can be considered as a rich source which, like a powerful mechanism, provides principles and concepts in order to design artificial computational methods for solving complex optimization problems.

Metaheuristic optimization algorithms, which are also called smart and modern optimization algorithms, are categorized as stochastic optimization algorithms employed for finding optimal solutions. The word "metaheuristic" was first adopted by Glover [4] when introducing TS as a novel heuristic method. Heuristic optimization methods are a set of algorithms for optimization of problems which search solution space to find optimal response randomly but purposeful and simple [4]. The metaheuristic optimization algorithms have outsourced approaches from local optimum and are capable of finding optimum solutions in wide ranges of optimization problems $[5,6]$.

Metaheuristic optimizers are methods which are inspired by studying the natural phenomena. Due to their potential and strength, the optimization algorithms have been used in many and various subjects related to sustainability and sustainable development including environmental sustainability, social sustainability, economic sustainability, sustainable energy resources, sustainable buildings, sustainable environment, and more. A variety of articles based on optimization techniques have been published in different international journals. Excellent exploitation and exploration strategies of metaheuristic optimization algorithms have made these algorithms a good alternative for solving optimization problems.

In recent decades, researchers have developed various types of metaheuristic optimization algorithms [7]. These methods have been expanded by mimicry of some well-known processes, primarily in biology, physics, chemistry, math, society, and nature [8]. There are different categorizations of metaheuristic optimization algorithms proposed in the literature [9,10]. Generally, algorithms inspired by nature can be divided into four main categories including EA, SI, PCMB algorithms, and finally the $\mathrm{HB}$ algorithm.

GSO [11,12], GAs [13], PSO [14], TLBO [15], HS [16], TS [4] and WCA [17] are the some of the well-known algorithms that are used in order to optimize different problems. A large number of writers in literature have addressed sustainability optimization. In [18], for energy systems, a new and comprehensive model for the evaluation of durability was introduced. This model follows a holistic approach which impacts sustainability. It addresses various disciplines, including energy, exergy, environment, society, technology education, and the energy system's dimension.

A multi-objective model of optimization, which offers a comprehensive method of maximizing sustainability through all three pillars, was introduced in [19]. This article provides a strategy for optimizing the supply chain networks that includes economic, environmental, and social sustainability as three pillars of sustainability. This provides a comprehensive overview of measures and indicators for evaluating the three pillars and links each indicator to a supply chain network portion. A multi-target optimizing model was modified to cover three cost goals as a part of the supply chain network: economic, environmental, and social sustainability.

In [20], a petrochemical network was planned for Kuwait by developing an optimization model where some sustainability indicators were used as objectives. In [21], in order to determine the configuration of industrial metal-fabrication systems, with the greatest sustainable efficiency in three sectors and six facilities, a methodology combined with Monte Carlo simulation was suggested. In [22], multi-objective optimizing the repair choice for infrastructures exposed to natural hazards with the greatest sustainable contribution was suggested.

In [23], in order to identify the most sustainable electricity generation planning scenario in Indonesia for 2050, a multi-target optimization model was presented. In [24], a method was designed 
to optimize sustainability of a combined heat and power generation system integrated wastewater treatment plant. In [25], sustainability optimization was also pointed out in the nuclear industry.

In [26], optimization models for the optimum implementation of selected sustainability activities called sustainability programs were designed to maximize the efficiency of the manufacturing industry in line with established budgetary and minimum threshold constraints on technological, social, and socio-economic parameters. In addition to modeling shown in this paper [26], a random process is proposed for searching the ANNs for the optimal durability system, the importance of the sample problem is described. Sensitivity analysis is performed to understand the model's behavior. It is noted that the performance of sustainability depends on constraints such as budget restrictions and performance criterion threshold values.

In [27], as a new optimization technique for the sustainable growth of supply chains, the TTS optimization concept was implemented. The TTS approach seeks to replace existing methods of optimization. Its main focus is on the timeframe to achieve a sustainable and stable condition of the system under consideration.

A decision-making issue with the quality-based product recovery was explored in [28] with multiple optimization goals, including economic, environmental, and societal performance of sustainability. In this article, MOEA was utilized for solving the MOOP problem and finding an optimal solution.

A principal contribution of this paper is its summary of a significant research review of all applicable optimization methods to sustainable building design and energy efficiency problems. A description of the popular heuristic optimization algorithms covering direct search, processes, and other bio-inspired algorithms is available. Because green energy resources, systems, and technologies are the major elements of sustainable development, optimization approaches used for sustainable energy resources, sustainable buildings in the literature are investigated and evaluated in details in the current paper.

The remainder of this paper is organized as follows. Section 2 presents sustainability. Section 3 identifies optimization, its concept, definition, objectives, and methodologies related to metaheuristic optimizers as well. Section 4 addresses optimization and sustainable development in the literature, given with concise explanations of its applications and contributions. Section 5 further addresses studies in this paper. Section 6 concludes the findings and purpose of this review paper.

\section{Sustainability}

\subsection{Concept of Sustainability}

It is obvious that sustainability is at the heart of this concept, focusing on the condition of the biophysical environment of the earth, particularly with regard to the use and depletion of natural resources. It is more a matter of finding a sort of permanent state to support the people of the earth or a part of it, without endangering the health of human beings, animals, and plants.

In this regard, other attempts have also been made for providing foundations, ideas, and concepts related to sustainability. The general concept of sustainability compared and contrasted by Brown et al. in [29] with different definitions and roots in order to move toward a common understanding (see Table 1). Brown et al. [29] concentrated on definitions including "sustainable biological resources use," "sustainable agriculture," "carrying capacity," "sustainable energy," "sustainable society and sustainable economy," and "sustainable development". Each one of them emphasized different subjects. In this context, roots of sustainability in accordance with the sustainability definitions consist of "ecological/carrying capacity," "resource/environment," "biosphere," and "critique of technology," "no growth-slow growth," and "ecodevelopment". In their view, these six meanings converge around two major aspects of results with focus on ecology and the economy [29]. 
Table 1. A summary of the sustainability definitions and concepts.

\begin{tabular}{|c|c|c|c|}
\hline $\begin{array}{c}\text { Roots of } \\
\text { Sustainability }\end{array}$ & Points of Emphasis & $\begin{array}{l}\text { Definitions of } \\
\text { Sustainability }\end{array}$ & Points of Emphasis \\
\hline $\begin{array}{l}\text { Ecological/carrying } \\
\text { capacity }\end{array}$ & $\begin{array}{c}\text { Maintenance of natural systems so } \\
\text { that they can support human life } \\
\text { and well-being }\end{array}$ & Carrying capacity & $\begin{array}{l}\text { Optimum and maximum ability } \\
\text { of Earth's systems to support } \\
\text { human life and well-being }\end{array}$ \\
\hline Resource/environment & $\begin{array}{l}\text { Promoting economic growth only } \\
\text { to the extent and in ways that do } \\
\text { not cause deterioration of natural } \\
\text { systems }\end{array}$ & $\begin{array}{c}\text { Sustainable use of } \\
\text { biological resources }\end{array}$ & $\begin{array}{l}\text { Maximum sustainable yield } \\
\text { from natural systems, such as } \\
\text { forests and fisheries }\end{array}$ \\
\hline Biosphere & $\begin{array}{l}\text { Concern with the impacts of } \\
\text { humans on the health of the Earth } \\
\text { and its ability to support human } \\
\text { populations }\end{array}$ & Sustainable agriculture & $\begin{array}{c}\text { Maintaining productivity of } \\
\text { farming during and after } \\
\text { disturbances such as floods and } \\
\text { droughts }\end{array}$ \\
\hline Critique of technology & $\begin{array}{l}\text { Rejection of the notion that science } \\
\text { and technology, by themselves, } \\
\text { will protect and save the Earth }\end{array}$ & Sustainable energy & $\begin{array}{l}\text { Renewable alternatives to fossil } \\
\text { fuel reliance to produce heat } \\
\text { energy }\end{array}$ \\
\hline No growth-slow growth & $\begin{array}{l}\text { Limits to the ability of the Earth to } \\
\text { support the health and well-being } \\
\text { of ever growing populations }\end{array}$ & $\begin{array}{l}\text { Sustainable society and } \\
\text { economy }\end{array}$ & $\begin{array}{c}\text { Maintaining human systems to } \\
\text { support economic and human } \\
\text { well-being }\end{array}$ \\
\hline Ecodevelopment & $\begin{array}{c}\text { Adapting business and economic } \\
\text { development activities to realities } \\
\text { of natural resource and } \\
\text { environmental limits }\end{array}$ & Sustainable development & $\begin{array}{c}\text { Promoting economic growth } \\
\text { only to the extent and in ways } \\
\text { that do not cause deterioration } \\
\text { of natural systems }\end{array}$ \\
\hline
\end{tabular}

Sustainability is a concept widely understood and discussed. In fact, it is subject to vast partiality and subjectivity. Therefore, sustainability is a multi-disciplinary concept, based on an understanding covering various aspects of life. The principle areas that impact sustainability are highlighted in Figure 1. In addition, the areas are in various ways intertwined. The social sphere affects the cultural realm, for example, while the economic sphere influences public policy.

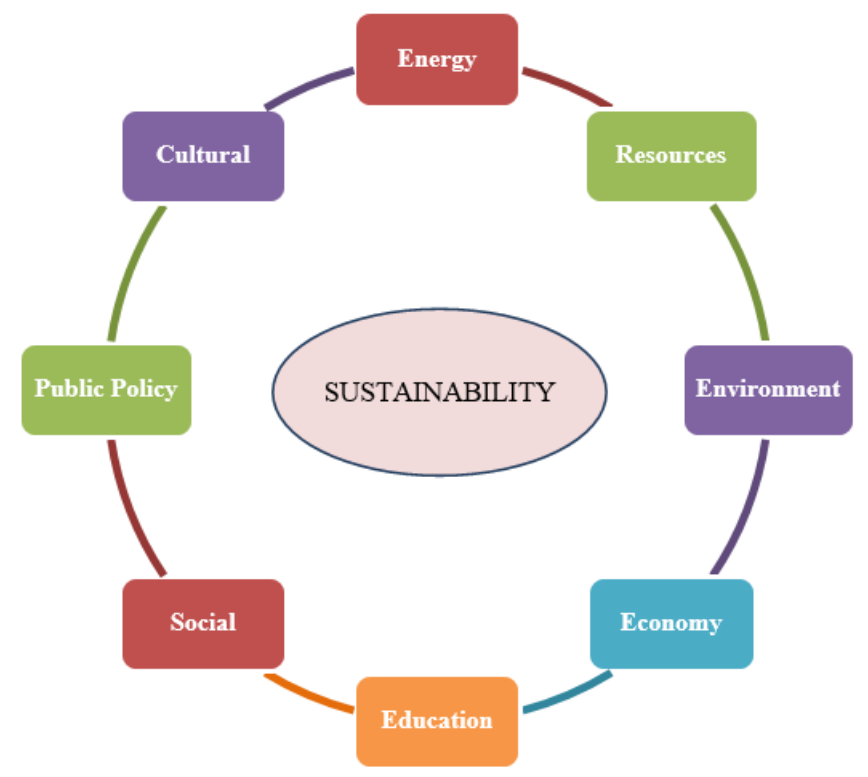

Figure 1. The backbone of sustainable development and the key areas for understanding the concept of sustainable development [18].

Overall, a sound and thorough analysis of every factor and element contributing directly or indirectly to this concept leads to an objective understanding and evaluation of sustainability. Nonetheless, an internationally accepted standard for sustainable assessment is not available. This is largely because models are often blamed for their subjectivity, their sense of sustainability, or their lack of clarity [18]. 


\subsection{Elements of Sustainability}

Optimization methods for environmental sustainability—social and economic—are developed separately. [19]. Since, energy can be seen as a key factor in poverty reduction and the improvement of living standards, energy resources and the sustainability dimensions must integrate together. Thus, technical dimension relating to functional and technological advantages is considered by some authors as energy resources sustainability. In this case, the sustainability measures for optimization consist of environmental, social, economic, and energy resources sustainability.

\section{Optimization}

Optimization is a search process for a specific problem according to special conditions of that problem. Optimization refers to finding a process of optimal values for a given network parameter using all feasible values for the minimization or maximization of network output. The goal of optimization is to discover the best feasible response with the consideration of the problem constraints. The presence of complex scientific and engineering problems leads to using optimization methods to solve the desired problem. Due to time consuming and complexity of exact methods, utilizing intelligent optimization algorithms has crucial importance.

Optimization of many complex scientific problems which require solutions with accurate computations and appropriate time cannot use classical methodologies. In this situation, nature can be considered as a rich source which, like a powerful mechanism, provides principles and concepts in order to design artificial computational methods for solving such complex optimization problems. Heuristic optimization methods are a set of algorithms for optimization problems which search in problem search space to find optimal response randomly, but purposeful and simple [30,31].

After developing a heuristic optimization algorithm, for instance TS, researchers found that some natural phenomena, despite being random, are interestingly moving toward near-optimal states. These optimization algorithms are usually inspired by nature. The metaheuristic optimization algorithms have outsourced approaches from local optimum and are capable of finding optimum solutions in a wide range of optimization problems [32,33]. General algorithms inspired by nature can be divided into four main categories: EAs, SI algorithms, PCMB algorithms, and finally HB algorithms.

The EAs are a subset of evolutionary computations and are categorized in the AI group. The evolutionary algorithms are inspired by the evolutionary and genetic behaviors of creatures. These algorithms consist of GAs [13], DE [34], BBO [35], and ES [36]. Other well-known algorithms of EAs include PBIL [37], GP [38], VCS [39], and NNA [40].

The second group of metaheuristic optimization algorithms are the SI algorithms which are usually inspired by intelligent behaviors of creatures in nature. A majority of algorithms belongs to the SI category, unlike the EAs class that only utilizes genetic laws. They always take full advantages of each solution in the search space to provide better solutions for optimal solving of a given problem [39].

\section{Optimization and Sustainable Development}

The definition of the concept of sustainable development is a good starting point for this section. Sustainable development is a term that has been widely used and for which many meanings have been suggested in the past three decades. Several papers have recently discussed the meaning of sustainability [41] and sustainable development $[42,43]$ and how it can be operationalized and identified [44].

Even if they are sometimes considered interchangeably, the concept of sustainable development is slightly separate from sustainable. It should be known that the concept of sustainable development includes a reference to development that is not necessary in order to sustain a system.

Sustainability is defined as "capacity for long-term development", while sustainable development is the mechanism through which sustainable development is achieved or considered [45]. "A dynamic process that allows everyone to realize their own potential and improve their quality of life so as 
to protect and improve the life-support systems of the world at the same time, as a way to achieve sustainable development as a process" [45] recalls the results of the Forum for the Future. A sustainable development can be the only solution to these problems.

Sustainable development is the synthesis of preservation of energy resources, environmental sustainability, economic sustainability, and social sustainability, as illustrated in Figure 2. Clean energy and technologies are a key component of sustainable development for three main purposes.

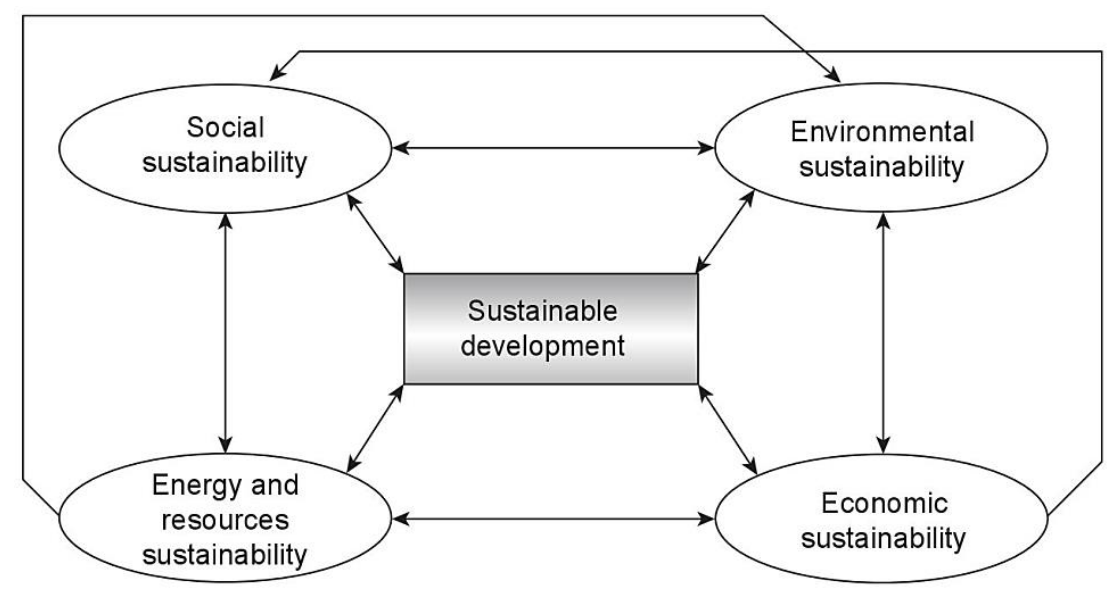

Figure 2. Factors affecting sustainable development interdependence [46].

Firstly, they generally produce less EI than other sources of energy. There are a wide range of green energy options. Secondly, they were not able to be depleted. When used in appropriate applications carefully, green energy resources can provide reliable and sustainable energy almost indefinitely. Thirdly, it promotes decentralization of systems and locally independent solutions, thus increasing the flexibility of the system and offering economic gains to small, fragmented communities. However, the small scale of the equipment also decreases the amount of time required from design to operation to make it more suitable to meet unpredictable production [46].

Indeed, the biggest problem with renewable energy such as wind and solar energies is that they are intermittent. Also, they would require warehouses full of massive batteries, and at this size, a major problem becomes apparent.

However, the life-cycle perspective is of paramount importance when evaluating EI. Moreover, when following this perspective, even in energy systems assimilated as renewable, there is high demand for fossil resources cumulated along the life-cycle stages, even higher than a conventional (fossil) "competitor".

Figure 3 illustrates the major considerations involved in developing green energy technologies including social, EIs, marketing, technological and economic factors. In addition to these considerations, a series of parameters (factors) can be identified which are important for developing green energy policies and strategies. These include information to the general public, environmental education, innovation stimulation, technology promotion, financing, and very important tools and techniques of elaborate evaluations.

For future sustainable energy environments, green energy technologies are expected to play a key role. Energy demand is likely to be the main factor deciding the role of green energy and technologies. Therefore, green electricity from renewable sources, such as hydraulic energy, solar, wind, geothermal energy, wave, biomass, etc., can be produced to address the energy demand. Green energy innovations are largely influenced by strong and influential patterns that are grounded in fundamental human needs. Wastes (e.g., waste-to-energy incineration plants converted into usable forms of energy) and biomass sources are considered to provide renewable energy/green energies.

To achieve a comprehensive sustainable development, using optimization methods and subsequently optimizing the objective functions of the problems in relation to energy resources 
sustainability, environmental sustainability, economic sustainability, and social sustainability is very essential. Green energy resources, systems, and technologies are the key components of accomplishing sustainable development, in the following optimization methods. They are applied to the sustainable energy and buildings in the literature, and are discussed and analyzed in detail.

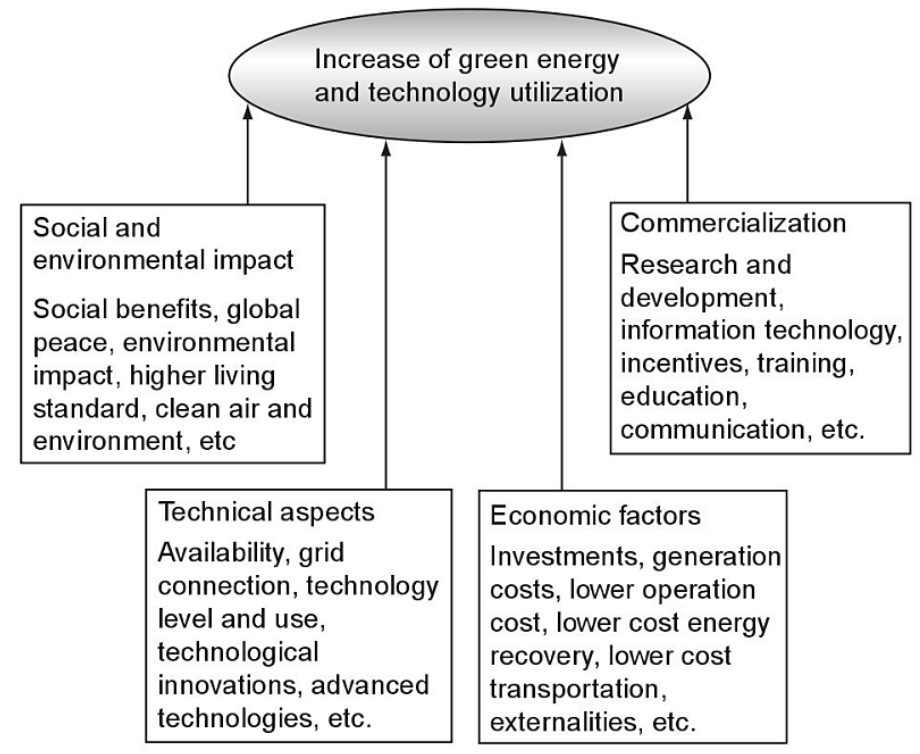

Figure 3. Considerations involved in development of green energy technologies [46].

\subsection{Optimization and Sustainable Energy}

The main focus of sustainable energy is to move towards electricity production and powering equipment by means other than fossil fuel consumption. Recently, there has been a shift in focus because the quantities of fossil fuel used to produce energy are too big. This means that dependence on fossil fuels was once considered untenable because these resources would be eradicated in the world. Today, however, because of the environmental impact of burning them, that dependency has been considered unsustainable. Now that the issue of global climate change has emerged, it is clear that the burning of fossil fuels is the primary cause for the release of carbon dioxide into the atmosphere. Therefore, because the fossil fuels have many carbon dioxide emissions, finding sustainable alternatives has become an imperative.

As a result, those interested in climate protection advocate sustainable energy as a means for reducing carbon emissions. This will inevitably lead to an increasing reliance on energy sources such as solar, wind, geothermal, hydro-electric, and sometimes nuclear. This focus on renewables is a somewhat narrower version of the concept of sustainable energy.

Another more comprehensive concept is to reduce the energy demand generated by consumer goods production. For example, by increasing the efficiency of energy resource usage, and/or by replacing toxic energy resources with less environmentally friendly energy sources, energy consumption typically decreases environmental effects. Such behavior will promote sustainable development and raise living standards through a cleaner climate. A sustainable supply of sources of energy, to be accomplished through the following, is provided by sustainable development:

- Sustainable energy resources available at a reasonable cost which can be used for all necessary tasks without detrimental societal effects. The generally accepted endpoints are energy resources like fossil fuels (coal, oil, and natural gas), and uranium. Others, such as sunshine, wind, and falls in water are generally regarded as renewable and relatively long-term sustainable [47]. Wastes and biomass fuel are sometimes seen as sustainable energy sources (convertible to useful energies through waste-to-energy incineration and other processes). 
- Efficient utilization of energy resources for improving their benefits while preventing their use. That recognizes that all energy resources are to a certain extent limitable, enabling them to contribute to the long-term growth and thus to a more sustainable development. In addition to energy sources which can eventually make cost-performing changes, the need for resources (energetic, material, etc.) will be reduced to create and sustain energy systems and devices and the related environmental impacts will also be reduced. [47].

Figure 4 shows that approximately 1/4 of global final energy consumption in 2017 was made by the residential sector (a total of 8918 Mtoe). Over the last few decades, this share has not changed significantly and it is projected to continue to be similar. The data source given in Figure 4 is the International Energy Agency. It describes the residential sector as the combined pool of all households in the region, also known as the household market [47].

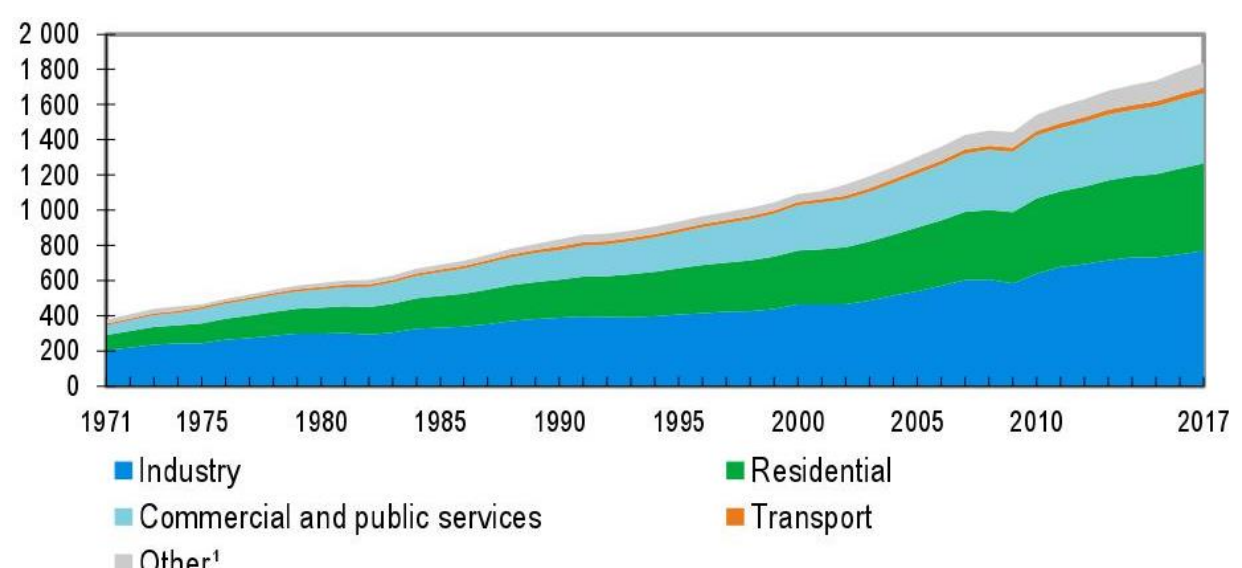

1973

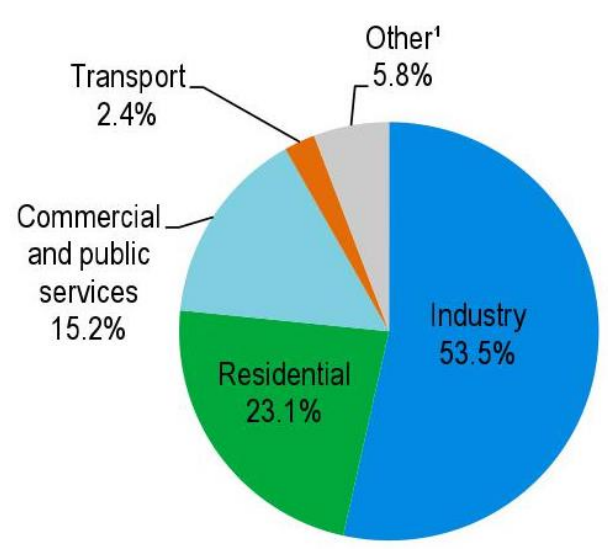

2017

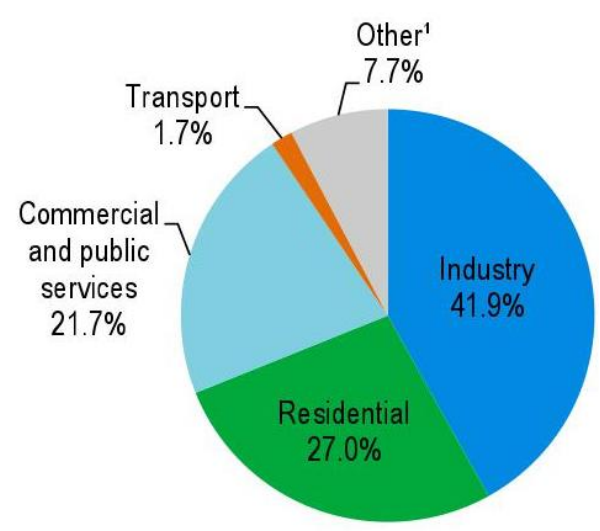

Figure 4. 1973 and 2017 shares of world electricity final consumption (Source: IEA, World Energy Balances, 2019).

In the transportation sector, roughly half the supply of renewable primary energy is used to produce electricity and heat in countries of the OECD. However, the majority of renewables in the residential, commercial, and public services sectors are being consumed globally. This is a result of the extensive use of organic solid fuels in developing countries' residential sectors. The global electricity and heat production are based on 38.6 percent of renewable energy; while 41.7 percent is spent on the residential, commercial, and government sector (see Figure 5). 


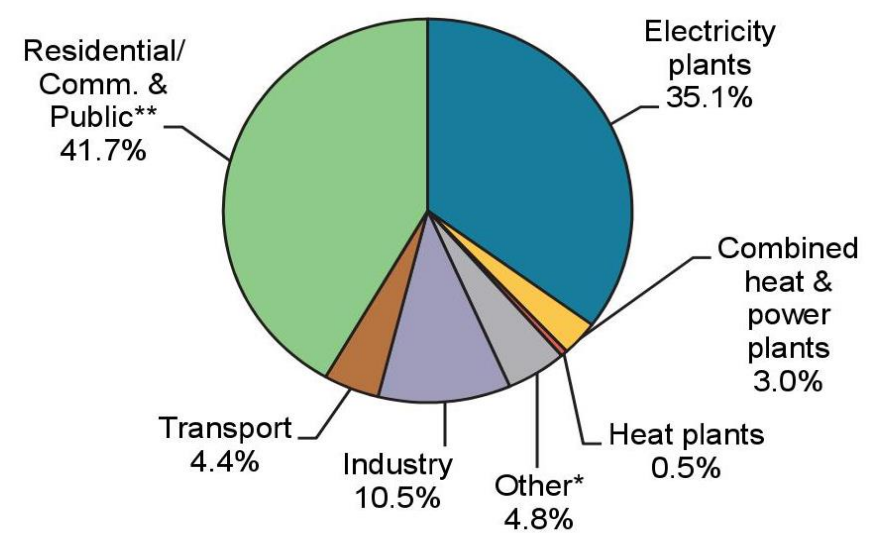

Figure 5. International sectoral renewable energy used in 2017.

In the following, the review was made on recent published papers in this topic. Table 2 shows the reviewed papers in the literature.

Table 2. Main characteristics of some the reviewed papers in the literature.

\begin{tabular}{|c|c|c|c|c|c|c|}
\hline \multirow{2}{*}{ Ref. } & \multirow{2}{*}{ Problem } & \multirow{2}{*}{$\begin{array}{l}\text { Optimization } \\
\text { Method }\end{array}$} & \multirow{2}{*}{ Objective Function } & \multicolumn{2}{|c|}{ Optimization } & \multirow{2}{*}{ Year } \\
\hline & & & & Single-objective & Multi-objective & \\
\hline [48] & Optimal power flow & MJAYA & $\begin{array}{ll}\text { - } & \text { Fuel cost } \\
\text { - } & \text { Emission cost } \\
\text { - } & \text { Power loss }\end{array}$ & $x$ & $\checkmark$ & 2019 \\
\hline [49] & $\begin{array}{l}\text { Optimization of Renewable } \\
\text { Energy Sources in a Microgrid }\end{array}$ & AFSA & Cost of generation & $\checkmark$ & $x$ & 2016 \\
\hline [50] & $\begin{array}{l}\text { Optimal integration of } \\
\text { renewable energy sources for } \\
\text { autonomous tri-generation } \\
\text { combined cooling, heating, } \\
\text { and power system }\end{array}$ & PSO & - Total cost & $\checkmark$ & $\times$ & 2018 \\
\hline [51] & $\begin{array}{l}\text { Optimal design of Microgrid's } \\
\text { network topology and } \\
\text { location of the distributed } \\
\text { renewable energy resources }\end{array}$ & HS & $\begin{array}{ll}\text { - } & \text { Cost } \\
\text { - } & \text { Power loss }\end{array}$ & $\times$ & $\checkmark$ & 2019 \\
\hline [52] & $\begin{array}{l}\text { Sustainable renewable energy } \\
\text { planning and wind farming } \\
\text { optimization }\end{array}$ & GAs & $\begin{array}{l}\text { - Cost of Energy } \\
\text { (LCOE) }\end{array}$ & $\checkmark$ & $x$ & 2018 \\
\hline [53] & $\begin{array}{l}\text { Sustainable Indonesian } \\
\text { electricity system }\end{array}$ & $\begin{array}{l}\text { Multi-objective } \\
\text { optimization model }\end{array}$ & $\begin{array}{l}\text { - } \quad \text { Cost of generation } \\
\text { - Lowest } \\
\mathrm{CO} 2 \text { emissions }\end{array}$ & $\times$ & $\checkmark$ & 2015 \\
\hline [54] & $\begin{array}{l}\text { Design of distributed energy } \\
\text { supply systems }\end{array}$ & $\begin{array}{l}\text { Mixed-integer linear } \\
\text { programming (MILP) }\end{array}$ & $\begin{array}{l}\text { - } \\
\text { - Total } \\
\text { annualized costs }\end{array}$ & $\times$ & $\checkmark$ & 2017 \\
\hline [55] & $\begin{array}{l}\text { Sustainable energy-generating } \\
\text { induction machine }\end{array}$ & $\begin{array}{l}\text { Random restart local } \\
\text { search optimization }\end{array}$ & $\begin{array}{ll}\text { - } & \text { Slip } \\
\text { - } & \text { Rotor current } \\
\text { - } & \text { Power factor } \\
\text { - } & \text { Starting toque }\end{array}$ & $\times$ & $\checkmark$ & 2019 \\
\hline [56] & Sustainable energy systems & P-graph model & - System cost & $\checkmark$ & $x$ & 2017 \\
\hline [57] & $\begin{array}{l}\text { Sustainable NOx emission } \\
\text { reduction at a coal-fired power } \\
\text { station }\end{array}$ & $\begin{array}{l}\text { Online neural } \\
\text { network modeling } \\
\text { and PSO }\end{array}$ & - NOx emission rate & $\checkmark$ & $x$ & 2019 \\
\hline [58] & Optimal design of HRES & $\begin{array}{l}\text { Monte Carlo } \\
\text { simulation and } \\
\text { (STRONG) }\end{array}$ & $\begin{array}{ll}\text { - } & \text { Power shortage cost } \\
\text { - } & \text { Energy storage cost } \\
\text { - } & \text { Power } \\
& \text { generation cost } \\
\text { - } & \text { Carbon emission }\end{array}$ & $x$ & $\checkmark$ & 2015 \\
\hline [59] & CHPED & SRPSO & - Generation cost & $\checkmark$ & $x$ & 2019 \\
\hline
\end{tabular}


In [48], Jaya's new version called MJAYA was presented with four different targets, reflecting the minimization of fuel cost, emission minimization, transmission power loss reduction, and the improvement of the tension profile, to solve the problem of the OPF. Comparing other reported approaches suggests that the MJAYA algorithm is preferable to other methods. The MJAYA proposal is a population-based optimization algorithm consisting of simple steps only using common control parameters (i.e., maximum number of iteration and population sizes). For further explanation, Figure 6 displays the suggested flowchart for the MJAYA algorithm for OPF resolution.

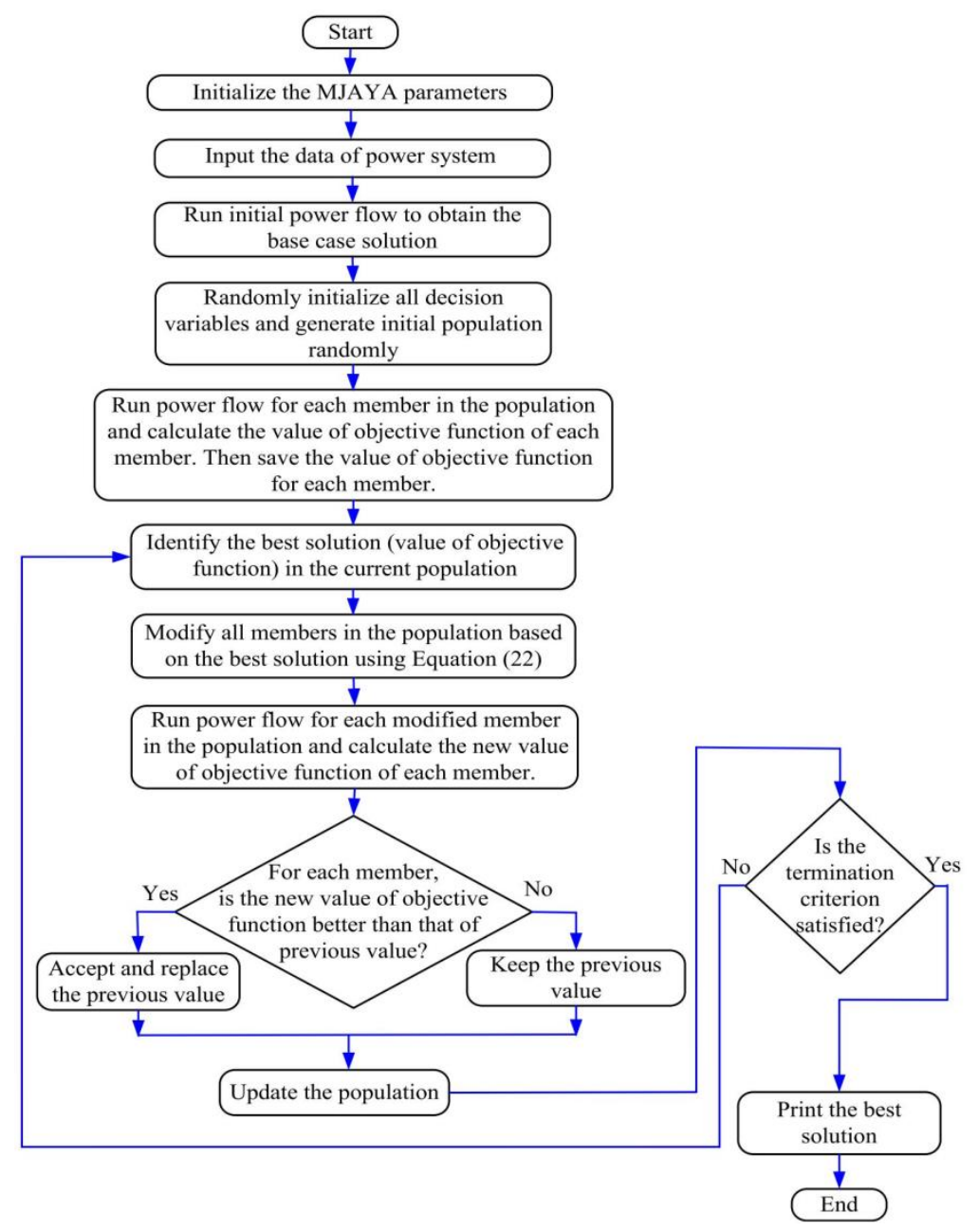

Figure 6. Diagram of MJAYA's proposed solution for the OPF [48].

In [60], a comparison was performed among four optimization algorithms in order to reduce power loss in the power distribution network equipped with renewable energy resources. These algorithms are GSA, BA, ICA and FPA. Placing RDGs such as wind energy and photovoltaic energy can lead to a reduction of power loss in an electrical power network. The suggested heuristic algorithms are used in this research to find the best site and size for RDGs in the distribution network to reduce energy loss. The results of ICA show its efficiency and superiority over the other algorithms that have been suggested.

In [49], an optimization algorithm is used for the optimal energy scheduling problem and the optimization of renewable energy sources in the micro-grid, called the Artificial Fish Swarm Algorithm. The efficiency of the algorithm is checked through a microgrid scenario to schedule generation. The findings are checked by comparison to the established multiplicative reduction algorithm for additive increase. 
In [50], a simulation model was developed for optimization of different configuration alternatives of autonomous renewable energy sources and CCHP systems for meeting cooling, heating, and electrical loads, based on the photovoltaic-thermal panel, wind turbine, thermal energy storage, electrical energy storage, absorption chiller, electric chiller, and electric heater. To optimize the process, a newly developed E-PSO algorithm is examined and validated. Figure 7 displays the simulation phase flowchart.

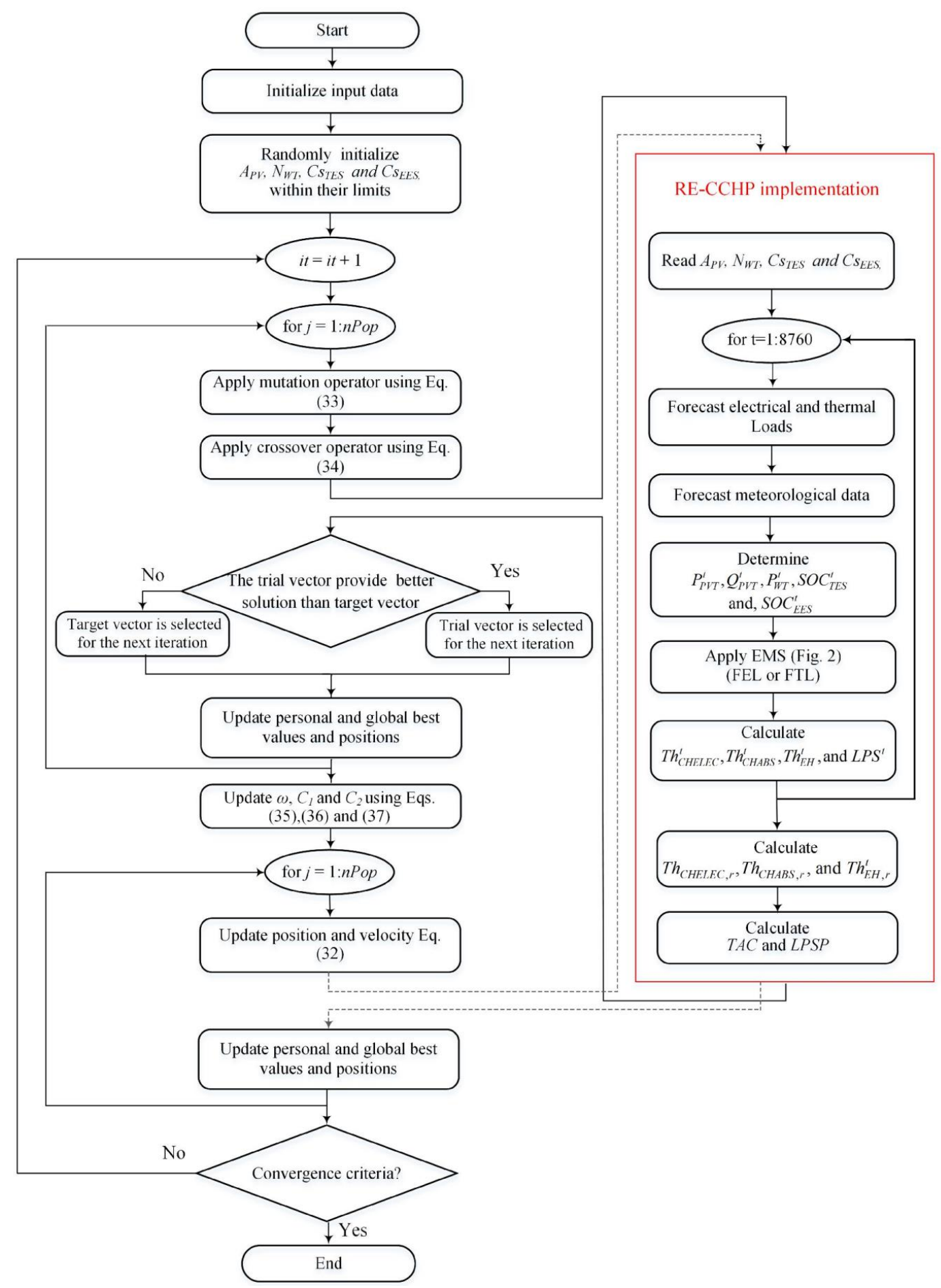

Figure 7. Diagram of the E-PSO algorithm simulation phase [50]. 
In [51], the combined topology of the network and the optimum placement of distributed renewables in a micro grid were addressed. To solve this problem of mutual optimization, the efficacy of the HS metaheuristic solver inspired by the jazz band music was analyzed. In this paper, two different approaches were considered. The first is a single objective problem formulation in which the classic HS is applied with certain adjustments. The second approach is to take into consideration a multi-target HS algorithm, which will develop a whole family of solutions at Pareto.

In [61], a hybrid ANP-BOCR-TOPSIS evaluation method was suggested to build a comprehensive assessment index system for selecting sustainable energy storage node optimization. At the same time, it was demonstrated that this technique can efficiently resolve such problems and be used in other areas. The system combination is seen in Figure 8.

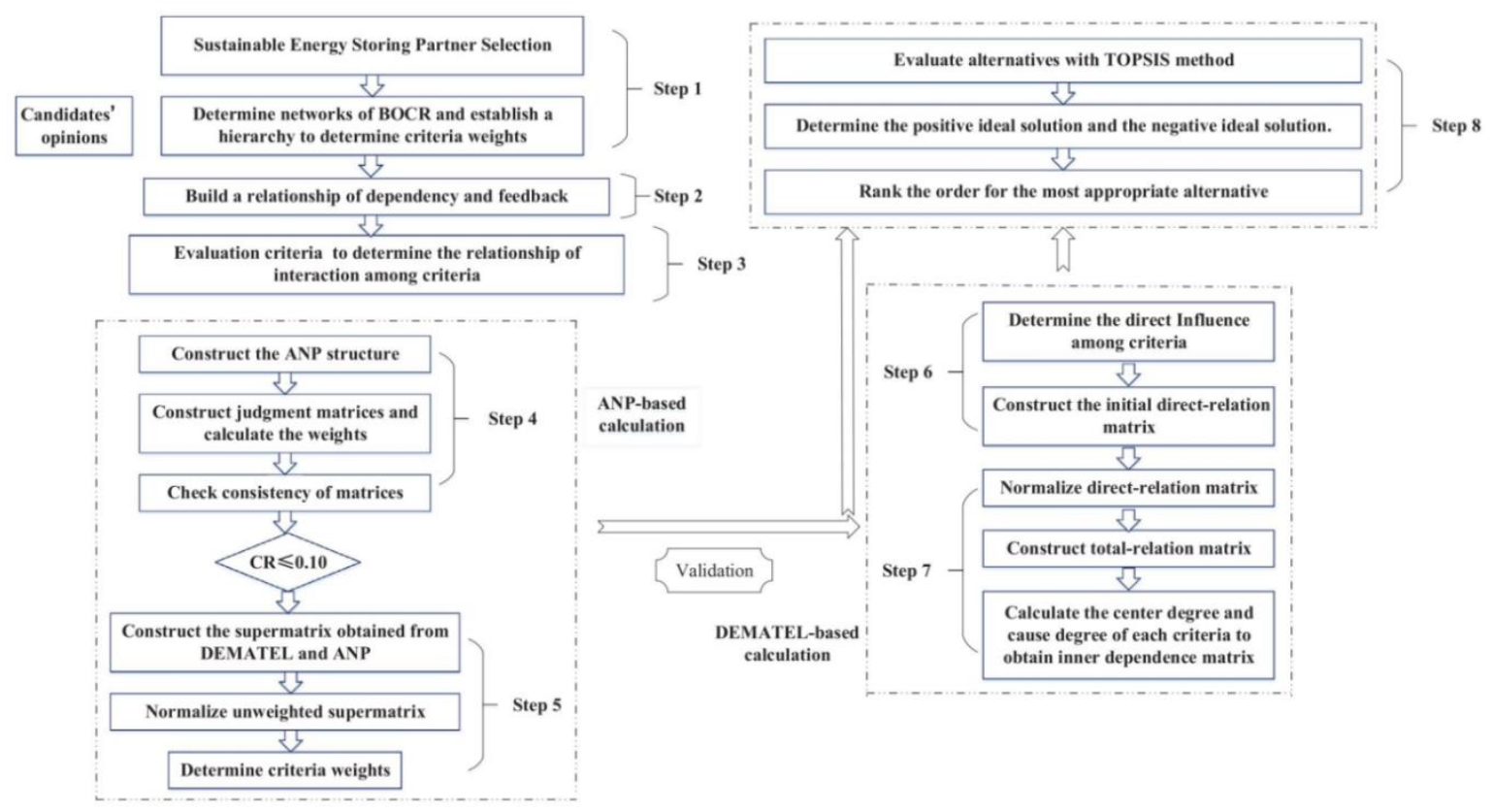

Figure 8. The ANP-BOCR-DEMATEL-TOPSE integrated system framework [61].

In order to determine the weights of all parameters, the approach BOCR was applied and the standards used by ANP were defined. Then the TOPSIS-based approach to classifying alternate firms was suggested. In order to assess the overall accuracy, the DEMATEL method was adopted. Eventually, the findings of ANP-BOCR-TOPSIS, DEMATEL-TOPSIS, and AHP-TOPSIS were related. The findings were also contrasted. The results show that the approach introduced had the potential to evaluate the parameters and was very effective for solving similar problems.

The effects of climate change, driven largely by fossil fuel consumption and unhealthy lifestyle use, promote a strong and far-reaching use of renewable energy sources. Reference [52] suggests the approach of computational GAs to optimize wind farms for the detection of both the sitting of the wind turbines and the levelized cost of energy to guarantee the optimal production of electricity and sustain fragile ecosystems. The model was used to determine suitable locations for the position of wind turbines on a complex field around a flight and evaluated the electricity offset in terms of demand and supply to facilitate localized, more stable energy networks.

Two steps are taken to improve the preparation and development of a wind farm: $a$ ) Using GAs to determine suitable wind turbine designs provided the circumstances in which winds are viewed, and; (b) Economic analyses focused on the expected wind turbine energy generation, calculating marginal costs of increasing energy production in the wind farm region. A flowchart in Figure 9 revealed the optimization pattern. 


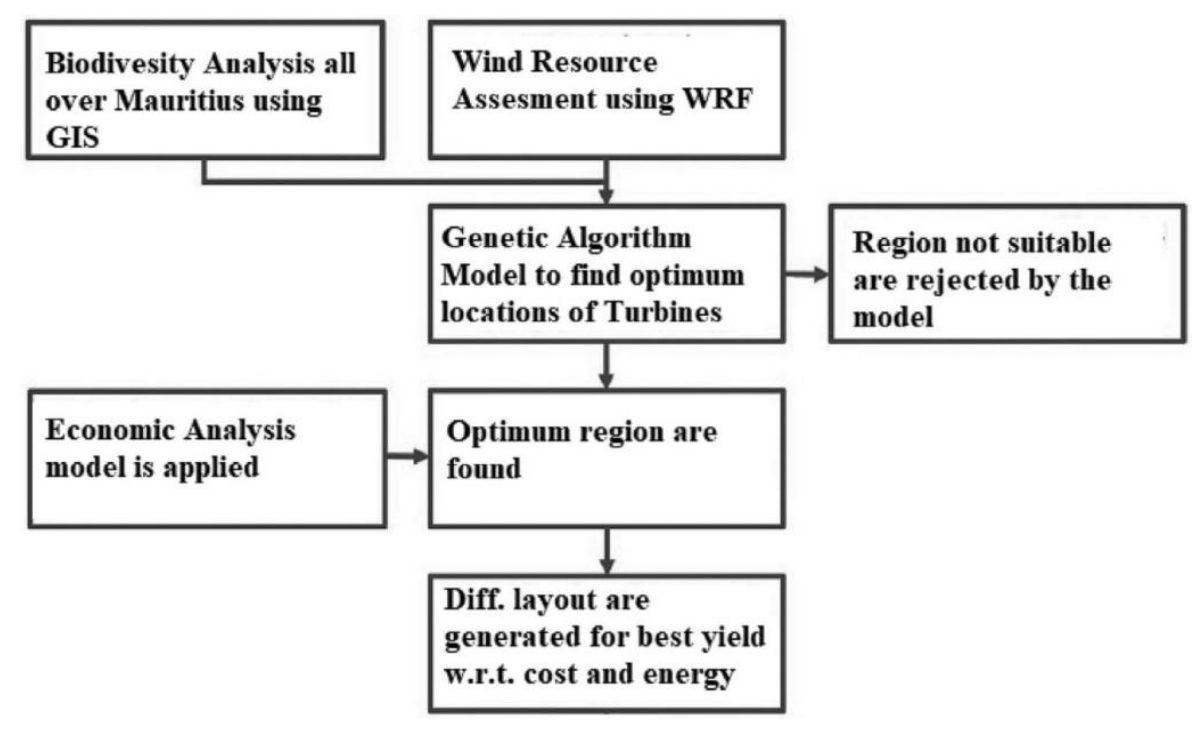

Figure 9. A flow chart that shows the pattern for optimization [52].

The results show the model's reliability and its future applicability to other locations pursuing sustainable energy preparation while at the same time maintaining economic stability and protecting the fragile ecosystems they have inherited.

Reference [62] used two models to analyze the consequences of these objectives, based on a number of mid and long-term scenarios, on the sustainable European energy system as well as the rest of the world. Firstly, the optimal configuration of the European electricity system is accomplished between 2030 and 2050 using the linear programming optimization approach for capability extension and unit contribution. The results for Germany are then used as inputs in the Multi-Regional Input-Output Analysis with the aim of analyzing the environmental and socio-economic effects of the new energy system. The results show this method's capacity for emissions of GHGs, cumulative energy demand and added value, and the creation of jobs.

In [53], a multi-target optimization model for a long-term power generation network in Indonesia was introduced. Between 2011 and 2050, the optimization model is performed. This paper seeks to assess local energy sources' cultural and environmental adequacy. The model includes two competing goal functions to obtain the lowest generation cost and lowest $\mathrm{CO}_{2}$ emissions while taking technology diffusion into consideration. The results show that all renewable energy should be developed in Indonesia and that imported coal and gas is needed.

Reference [63] provides an overview of sustainable energy system design and development focused on the context for superstructure optimization and the guidelines on LCO. There were a series of research challenges, such as (1) systematic generation of comprehensive super-structures for processes, (2) super structured optimization models that integrate technology-economic assessment and LCO, (3) effective computational algorithms to resolve non-linear optimization issues.

For the design of sustainable energy supply systems, the concept of min-max robust multi-objective optimization was applied in [54]. This article introduces a mixed-integer linear problem formula, incorporating uncertainties in sustainable energy system design. A Pareto front can therefore still be derived. The problem formulation represented transfers the important theoretical concept of min-max robust multipurpose optimization to engineering for the design of energy systems that are sustainable.

A random restart of the local search optimization process for efficient induction production of energy was examined in [55]. Several experiments have recently been designed to improve induction machines operating efficiency with optimization technology. However, current techniques failed to improve the induction machines efficiencies. An HC-LSO technology was designed to resolve this efficiency problem. Figure 10 shows the HC-LSO technique structure diagram. 


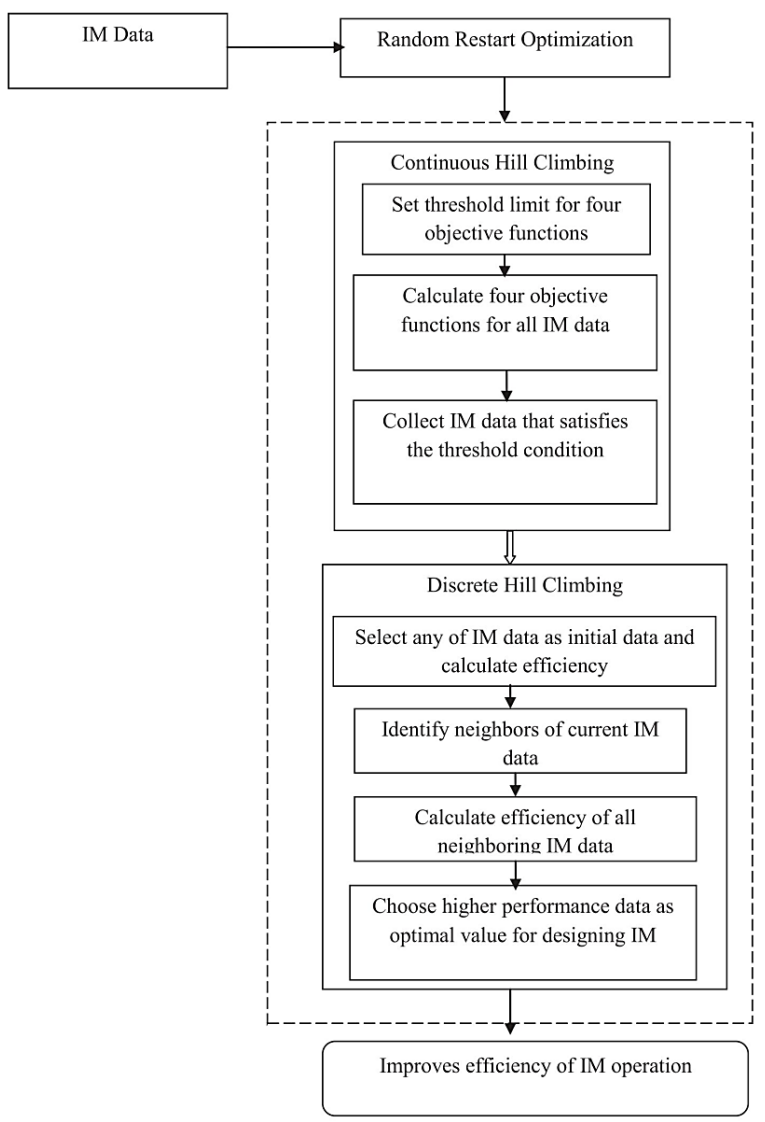

Figure 10. Hill climbing-optimization of HC-LSO (Hill-LSO) system configuration diagram [55].

A P-graph model is developed in [56] to optimize sustainable energy systems over a multi-period period. The model is capable of synthesizing scalable structures that are capable of addressing differences in the supply and demand of raw materials. In addition, the P-graph model is also capable of generating near-optimal solutions that provide information that may be important to decision-makers, such as structural features that are specific to a range of good solutions. The method built in this study is outlined in two case studies.

In [57], using ANNs model and PSO over two years of operation a 490 gross megawatt subcritical tangential coal fired boiler is built and implemented. There is also a hybrid optimization and control strategy using multiple methods of optimization and control, including machine learning [57].

In [64], the recent model of energy planning, energy projection models, and renewable energy integration models were studied and reviewed in numerous ways for minimum cost of energy, minimum $\mathrm{CO}_{2}$, and sustainable development. Various techniques and tools for modeling are also investigated and discussed.

In [65], a summary of trends in science (1999-2009) was provided regarding the utilization of the optimization methods for design, planning, and control problems related to renewable resources and sustainable energy. A review of more than 200 papers in the fields of renewable energy and computer optimization from leading publications provides interesting conclusions which can be of use for researchers in fields of green energy.

In [66], the power and supply sector developments were reviewed. The role of modeling and optimization as a tool for sustainable energy systems was analyzed as well as the future prospect of optimization modeling. Additionally, in [67], the different methodologies of optimal sizing of renewable hybrids energy systems were reviewed.

In [58], the use of simulation from Monte Carlo and simulation optimization techniques for optimal HRES design in uncertain environments were investigated. The proposed model takes into 
consideration not only the power generation, allocation, and transportation systems within the HRES framework, but PV equipment, wind and diesel electric power generators, and energy storage systems at each power plant.

In [68], numerous different tools for modeling a renewable energy project were examined for simulation and optimization. The models examined in this document were divided into various project subgroups: 'Multi-scale RE Tools', 'District Level Tools', and 'Regional Level Tools'. Tools for similarities and differences are contrasted among the different categories. Reference [69] provides a timely review of state-of-the-art energy planning for multi-target energy resources.

In addition, Reference [70] presents an exhaustive review of applied optimization algorithms for energy-efficient scheduling based on constraints and objectives related to energy. In this article, many methods including swarm and evolutionary algorithms for solving energy-based problems were discussed and analyzed. Figure 11 identifies swarm and evolutionary algorithms used to solve energy-related scheduling problems.

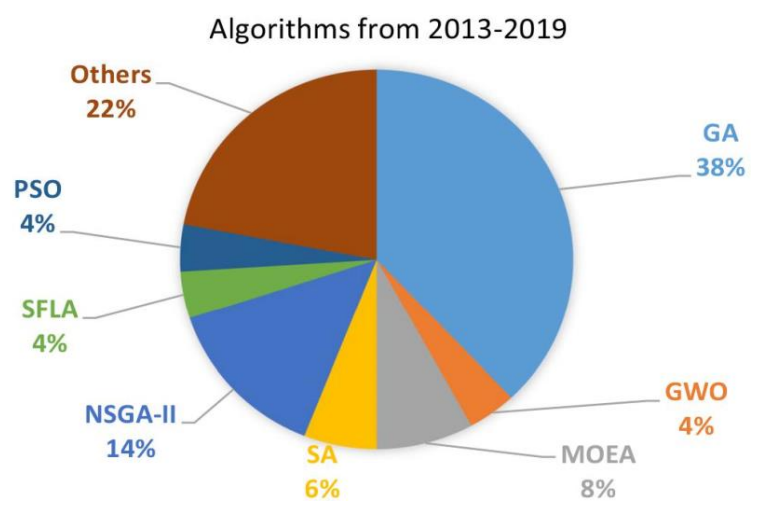

Figure 11. Swarm and evolutionary algorithms for solving energy-related scheduling problems.

Reference [71] also discusses HS algorithm implementations in energy systems. Various improved versions of the HS approach are implemented in the present study, and a comprehensive review in the field of HS implementation for energy system issues is conducted.

The SRPSO algorithm was used in a comparison to solve the problem of CHPED by taking into account fuel costs and power losses, and thereafter to obtain sustainable energy [59]. The SRPSO algorithm is an improved form of PSO.

\subsection{Optimization and Sustainable Buildings}

Buildings around the world consume a substantial amount of energy, about $1 / 3$ of the total primary energy resources. In those conditions, effective building energy management is critical in achieving a low carbon environment and potentially faster sustainability. The future generation of buildings is increasingly moving through energy-efficient buildings that allow smart building control. Furthermore, the energy source is an important element in building sustainability. Thus, in world sustainable development strategies, the building industry is attracting increased attention. This is due to its energy consumption and emissions of GHGs in the construction sector.

The concepts of sustainable design, which are widely considered in the sustainable assessment frameworks, were formulated by Hill and Bowen [72]. However, there is still no common definition of a sustainable building. While lowering the energy demand of buildings, lower Canada dealt with climate change criteria for sustainable construction in 2007 and stressed the importance of emissions of GHG [73].

In principle, a sustainable building, based on ecological values and resource efficiency, was in theory often seen as a safe building environment [74]. In countering this idea, a highly efficient building is described by improving the situation, design, construction, operation, maintenance, and removal of 
energy, which has less impact on health and the environment and fewer electricity, water, and materials throughout the lifetime [75].

The U.S. EPA reported that sustainable construction is the realistic practice of building structures by using environmentally responsible technologies, resource efficiencies, and the minimization of their lives from location until deconstruction [76]. Table 3 lists impacts that the EPA states are expected to minimize sustainable buildings (in view of their role, environmental effects are primarily taken into consideration).

Table 3. Environmental resources and impacts reduced by EPA re-adaptation in a sustainable building [77].

\begin{tabular}{|c|c|c|c|}
\hline Resource Consumption & Environmental Impact & $\rightarrow$ & Ultimate Effects \\
\hline $\begin{array}{ll}\text { - } & \text { Energy } \\
\text { - } & \text { Water } \\
\text { - } & \text { Materials } \\
\text { - } & \text { Site } \\
\text { - } & \text { Biodiversity }\end{array}$ & $\begin{array}{ll}\text { - } & \text { Waste } \\
\text { - } & \text { Air pollution } \\
\text { - } & \text { Water pollution and } \\
& \text { storm-water run off } \\
\text { - } & \text { Indoor pollution } \\
\text { - } & \text { Heat islands }\end{array}$ & $\rightarrow$ & $\begin{array}{ll}\text { - } & \text { Harm to Human Health } \\
\text { - } & \text { Environment Degradation } \\
\text { - } & \text { Loss of Resources }\end{array}$ \\
\hline
\end{tabular}

Many studies have been performed regarding low-energy buildings. Figure 12 illustrates the numbers of studies on low energy buildings obtained in the Science Direct database after 2000, by searching for "low," "energy," and "built-up" [78].

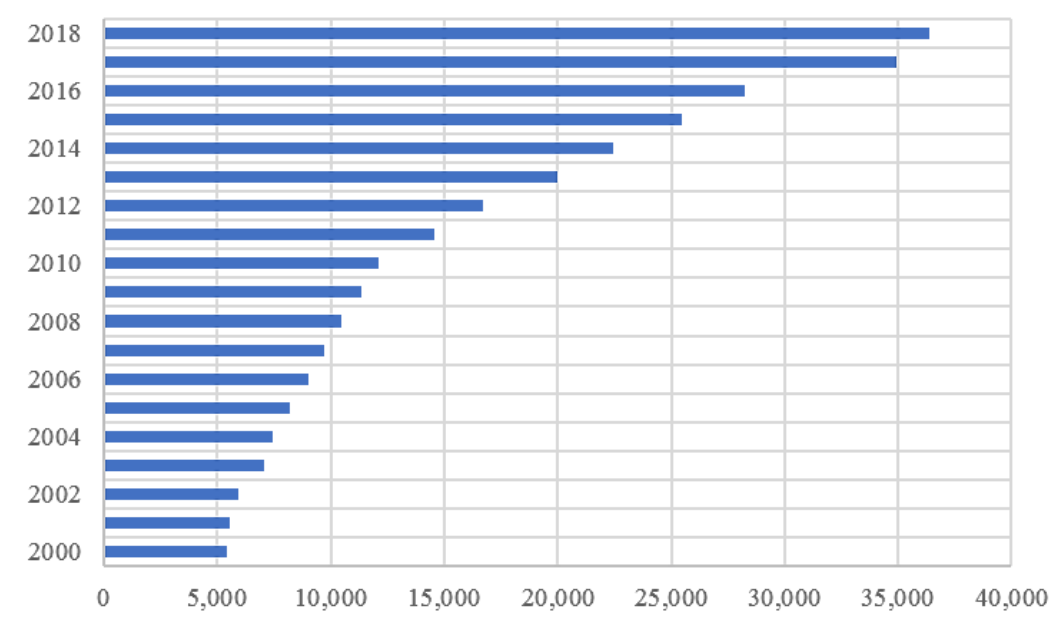

Figure 12. Number of Science Direct studies in the energy-efficient buildings after 2000.

The proposed literature review shows that optimization of BEO is an extremely complex process involving a broad range of potential objective functions and design variables as shown in this Figure 13. The main issues are mentioned. The target functions can include measures of energy, climate, economics, and/or comfort. Building structure, envelope, and energy systems can be related to the design variables.

There are many objective functions and main design variables in literature. In this study, the review was performed on papers concerning sustainable buildings from the energy perspective. Table 4 shows the reviewed papers in the literature. 


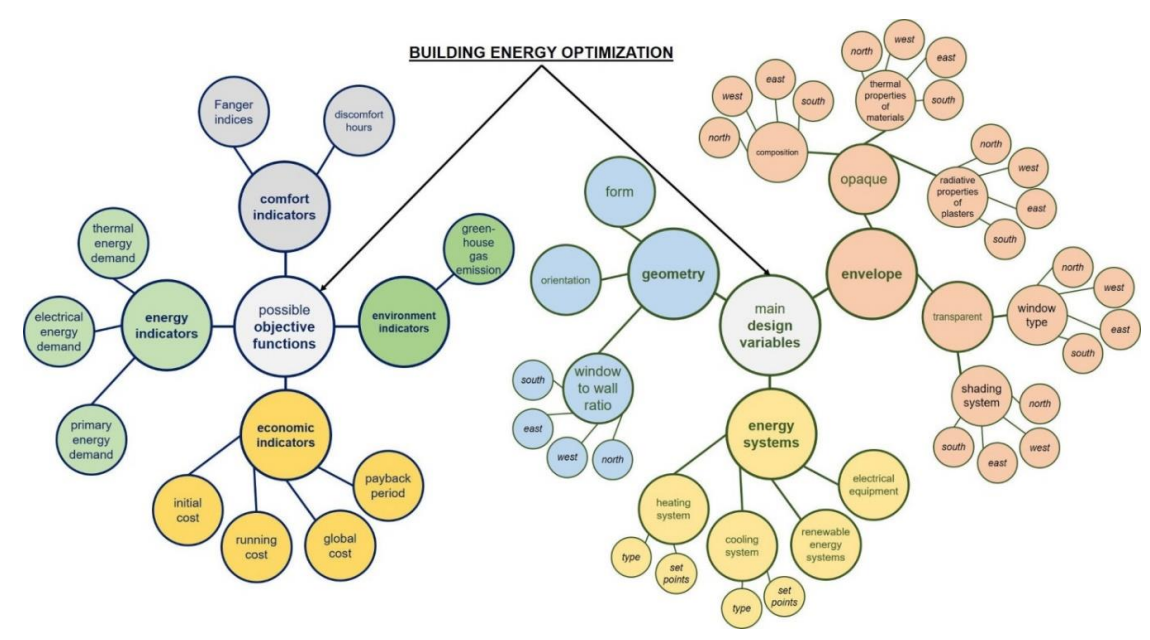

Figure 13. Optimization of Building Energy (BEO) including possible target functions and architecture core variables.

Table 4. Main characteristics of the reviewed papers in the literature.

\begin{tabular}{|c|c|c|c|c|c|c|}
\hline \multirow{2}{*}{ Ref. } & \multirow{2}{*}{ Problem } & \multirow{2}{*}{ Optimization Method } & \multirow{2}{*}{ Objective Function } & \multicolumn{2}{|c|}{ Objective Type } & \multirow{2}{*}{ Year } \\
\hline & & & & Single & Multi & \\
\hline [79] & Benchmark of BEO problems & SA, GAs and etc. & the energy consumption & $\checkmark$ & $\times$ & 2019 \\
\hline [80] & $\begin{array}{l}\text { Explore the best plan to maximize } \\
\text { energy efficiency in buildings }\end{array}$ & GAs & $\begin{array}{l}\text { Air conditioning and lighting energy } \\
\text { consumption }\end{array}$ & $x$ & $\checkmark$ & 2019 \\
\hline [81] & $\begin{array}{l}\text { To predict building energy } \\
\text { consumption }\end{array}$ & $\begin{array}{l}\text { An enhanced hybrid } \\
\text { model based on the } \\
\text { ARIMA, SVRs and PSO }\end{array}$ & energy consumption & $\checkmark$ & $x$ & 2019 \\
\hline [82] & $\begin{array}{l}\text { Stand-alone and grid-connected } \\
\text { zero/low energy buildings and their } \\
\text { energy systems }\end{array}$ & $\begin{array}{l}\text { Coordinated optimal } \\
\text { design method }\end{array}$ & $\begin{array}{l}\text { - Total cost } \\
\text { - the accumulated unmet power } \\
\text { - the accumulated unmet } \\
\text { cooling load }\end{array}$ & $x$ & $\checkmark$ & 2019 \\
\hline [83] & Building Energy Design & GAs & $\begin{array}{l}\text { - annual thermal energy demand } \\
\text { annual electrical } \\
\text { energy demand } \\
\text { annual percentage of } \\
\text { discomfort hours over } \\
\text { occupied hours }\end{array}$ & $x$ & $\checkmark$ & 2019 \\
\hline [84] & $\begin{array}{c}\text { Thermal Energy Performance of an } \\
\text { Academic Building }\end{array}$ & GAs & $\begin{array}{l}\text { - } \quad \text { Temperature profile } \\
\text { - } \quad \text { Electricity Consumption } \\
\text { - Thermal Comfort }\end{array}$ & $x$ & $\checkmark$ & 2019 \\
\hline [85] & Building energy optimization & MACO & Building annual end-use energy & $\checkmark$ & $x$ & 2018 \\
\hline [86] & $\begin{array}{l}\text { Reduce energy demand for buildings } \\
\text { and maximize thermal comfort }\end{array}$ & $\begin{array}{ll}- & \text { ANN } \\
- & \text { NSGA-II } \\
- & \text { Monte } \\
& \text { Carlo method }\end{array}$ & $\begin{array}{l}\text { - } \quad \text { Energy demand } \\
\text { - } \quad \text { Comfort time }\end{array}$ & $x$ & $\checkmark$ & 2018 \\
\hline [87] & $\begin{array}{l}\text { HVAC setpoint scheduling aiming at } \\
\text { reducing energy consumption }\end{array}$ & $\begin{array}{ll}- & \text { ANN } \\
- & \text { GAs }\end{array}$ & $\begin{array}{l}\text { - Energy demand } \\
\text { - Energy cost }\end{array}$ & $x$ & $\checkmark$ & 2018 \\
\hline [88] & $\begin{array}{l}\text { The model predictive control based on } \\
\text { the historical building data }\end{array}$ & $\begin{array}{ll}- & \text { Regression tree } \\
- & \text { Random forest }\end{array}$ & $\begin{array}{l}\text { - Thermal comfort } \\
\text { - Energy use }\end{array}$ & $x$ & $\checkmark$ & 2018 \\
\hline [89] & $\begin{array}{l}\text { Energy performance improvement of } \\
\text { residential buildings }\end{array}$ & $\begin{array}{ll}- & \text { ANN } \\
- & \text { NSGA-II } \\
- & \text { MOPSO } \\
- & \text { MOGA } \\
- & \text { MODE }\end{array}$ & $\begin{array}{ll}\text { - } & \text { Energy demand } \\
\text { - } & \text { Lifecycle cost } \\
\text { - } & \mathrm{CO}_{2} \text { emissions } \\
\text { - } & \text { Thermal comfort }\end{array}$ & $x$ & $\checkmark$ & 2017 \\
\hline
\end{tabular}


Table 4. Cont.

\begin{tabular}{|c|c|c|c|c|c|c|}
\hline \multirow{2}{*}{ Ref. } & \multirow{2}{*}{ Problem } & \multirow{2}{*}{ Optimization Method } & \multirow{2}{*}{ Objective Function } & \multicolumn{2}{|c|}{ Objective Type } & \multirow{2}{*}{ Year } \\
\hline & & & & Single & Multi & \\
\hline [90] & $\begin{array}{l}\text { The optimization of the thermal } \\
\text { behavior of building envelope }\end{array}$ & GAs & $\begin{array}{ll}\text { - } & \text { Energy consumption } \\
\text { - } & \text { Net present value } \\
\text { - } & \text { Payback period }\end{array}$ & $\times$ & $\checkmark$ & 2017 \\
\hline [91] & $\begin{array}{c}\text { Exergy and exergoeconomic } \\
\text { optimization as concerns building } \\
\text { energy design }\end{array}$ & $\begin{array}{c}\text { NSGA-II } \\
\& \\
\text { MCDM methods }\end{array}$ & $\begin{array}{ll}\text { - } & \text { Energy and Exergy use } \\
\text { - } & \text { Exergy efficiency } \\
\text { - } & \text { Exergy destruction } \\
\text { - } & \mathrm{CO}_{2} \text { emissions } \\
\text { - } & \text { Financial indicators }\end{array}$ & $x$ & $\checkmark$ & 2017 \\
\hline [92] & $\begin{array}{l}\text { Minimizing lifecycle cost and } \\
\text { emissions, ensuring, at the same time, } \\
\text { higher thermal satisfaction of building } \\
\text { occupants }\end{array}$ & HS & $\begin{array}{ll}\text { - } & \text { Lifecycle cost } \\
\text { - } & \text { Lifecycle emissions } \\
\text { - } & \text { Thermal comfort }\end{array}$ & $x$ & $\checkmark$ & 2017 \\
\hline [93] & $\begin{array}{l}\text { Increase the energy performance for } \\
\text { space heating and domestic hot water } \\
\text { production in residential buildings }\end{array}$ & GAs & $\begin{array}{ll}\text { - } & \text { energy consumption } \\
\text { - } & \text { Financial indicators }\end{array}$ & $x$ & $\checkmark$ & 2017 \\
\hline [94] & Building energy retrofit & $\begin{array}{l}\text { Multi-objective energy } \\
\text { hub optimization }\end{array}$ & $\begin{array}{l}\text { - Lifecycle cost } \\
\text { - Lifecycle GHGs emissions }\end{array}$ & $x$ & $\checkmark$ & 2017 \\
\hline [95] & $\begin{array}{l}\text { The energy performance of green } \\
\text { building envelopes }\end{array}$ & NSGA-II & $\begin{array}{l}\text { - Envelope construction cost } \\
\text { - Thermal energy demand } \\
\text { - Window opening rate }\end{array}$ & $x$ & $\checkmark$ & 2017 \\
\hline [96] & $\begin{array}{l}\text { Optimize the thermal and daylight } \\
\text { performance of school buildings }\end{array}$ & SPEA-2 & $\begin{array}{ll}\text { - } & \text { Energy demand } \\
\text { - } & \text { Useful daylight illuminance } \\
\text { - Summer thermal discomfort }\end{array}$ & $x$ & $\checkmark$ & 2017 \\
\hline [97] & $\begin{array}{l}\text { Find resilient cost-optimal retrofit } \\
\text { solutions }\end{array}$ & NSGA-II & $\begin{array}{l}\text { - } \quad \text { Thermal energy demand } \\
\text { - } \quad \text { energy consumption } \\
\text { - } \quad \text { lobal cost }\end{array}$ & $x$ & $\checkmark$ & 2016 \\
\hline [98] & $\begin{array}{l}\text { The improvement of the global overall } \\
\text { energy performance of office buildings }\end{array}$ & $\begin{array}{l}\text { Multi-criterion building } \\
\text { envelope optimization }\end{array}$ & $\begin{array}{l}\text { - } \quad \text { Energy demand } \\
\text { - } \quad \text { Visual comfort }\end{array}$ & $x$ & $\checkmark$ & 2016 \\
\hline [99] & $\begin{array}{c}\text { The design optimization of a residential } \\
\text { building }\end{array}$ & $\begin{array}{ll}- & \text { GAs } \\
\text { - } & \text { Morris screening } \\
\text { method for } \\
\text { sensitivity analysis }\end{array}$ & $\begin{array}{l}\text { - Energy demand } \\
\text { - } \quad \text { Discomfort hours }\end{array}$ & $x$ & $\checkmark$ & 2016 \\
\hline [100] & $\begin{array}{l}\text { Building energy behavior } \\
\text { simulation-based optimization }\end{array}$ & NSGA-II & $\begin{array}{l}\text { - Cooling energy demand } \\
\text { - Lighting energy demand }\end{array}$ & $x$ & $\checkmark$ & 2016 \\
\hline [101] & $\begin{array}{c}\text { Sustainable building } \\
\text { design }\end{array}$ & NSGA-II & $\begin{array}{l}\text { - } \quad \text { Thermal energy demand } \\
\text { - } \quad \text { Electricity demand } \\
\text { - } \quad \mathrm{CO}_{2} \text { emissions } \\
\text { - } \quad \text { Comfort level }\end{array}$ & $x$ & $\checkmark$ & 2016 \\
\hline [102] & $\begin{array}{l}\text { Finding optimal solutions of envelope } \\
\text { design }\end{array}$ & Mono- and MOPSO & $\begin{array}{l}\text { - } \quad \text { Hating energy demand } \\
\text { - } \quad \text { Cooling energy demand } \\
\text { Lighting energy demand }\end{array}$ & $x$ & $\checkmark$ & 2016 \\
\hline [103] & Design of energy systems for buildings & NSGA-II & $\begin{array}{l}\text { - } \quad \text { Energy use (heating, cooling) } \\
\text { - Investment cost }\end{array}$ & $x$ & $\checkmark$ & 2015 \\
\hline [104] & Building energy optimization & $\begin{array}{ll}- & \text { NSGA-II } \\
\text { - } & \text { MILP }\end{array}$ & $\begin{array}{l}\text { - Annual carbon emissions } \\
\text { - } \quad \text { Annual running costs } \\
\text { - Investment cost }\end{array}$ & $x$ & $\checkmark$ & 2015 \\
\hline [105] & $\begin{array}{l}\text { During design retrofit, multi-objective } \\
\text { optimization }\end{array}$ & $\begin{array}{ll}- & \text { GAs } \\
\text { - } & \text { ANNs }\end{array}$ & $\begin{array}{ll}\text { - } & \begin{array}{l}\text { Energy demand } \\
\text { (heating, cooling) }\end{array} \\
\text { - } & \text { Retrofit cost } \\
\text { - } & \text { Thermal discomfort hours }\end{array}$ & $x$ & $\checkmark$ & 2014 \\
\hline
\end{tabular}

In [106], for solving near-zero energy-building design problems, multi-objective optimizing algorithms were compared. [107] provides the software to support the selection of energy efficiency 
measures both for newly constructed buildings and for existing ones. The methodology of optimization is a MINLP problem. This study addressed issues of building optimization, both single and multi-objective. The objective is to generate annual energy consumption.

A new systematic method for tackling this difficult task was introduced in [83]. It is called "Harlequin," and it optimizes building energy efficiency multi-phase and multi-objectivity. Many architecture variables related to building structure, envelope, and energy systems are designed in three steps. Harlequin is a multi-stage and multi-target method for building energy design optimization. This indicates three phases as shown in Figure 14.

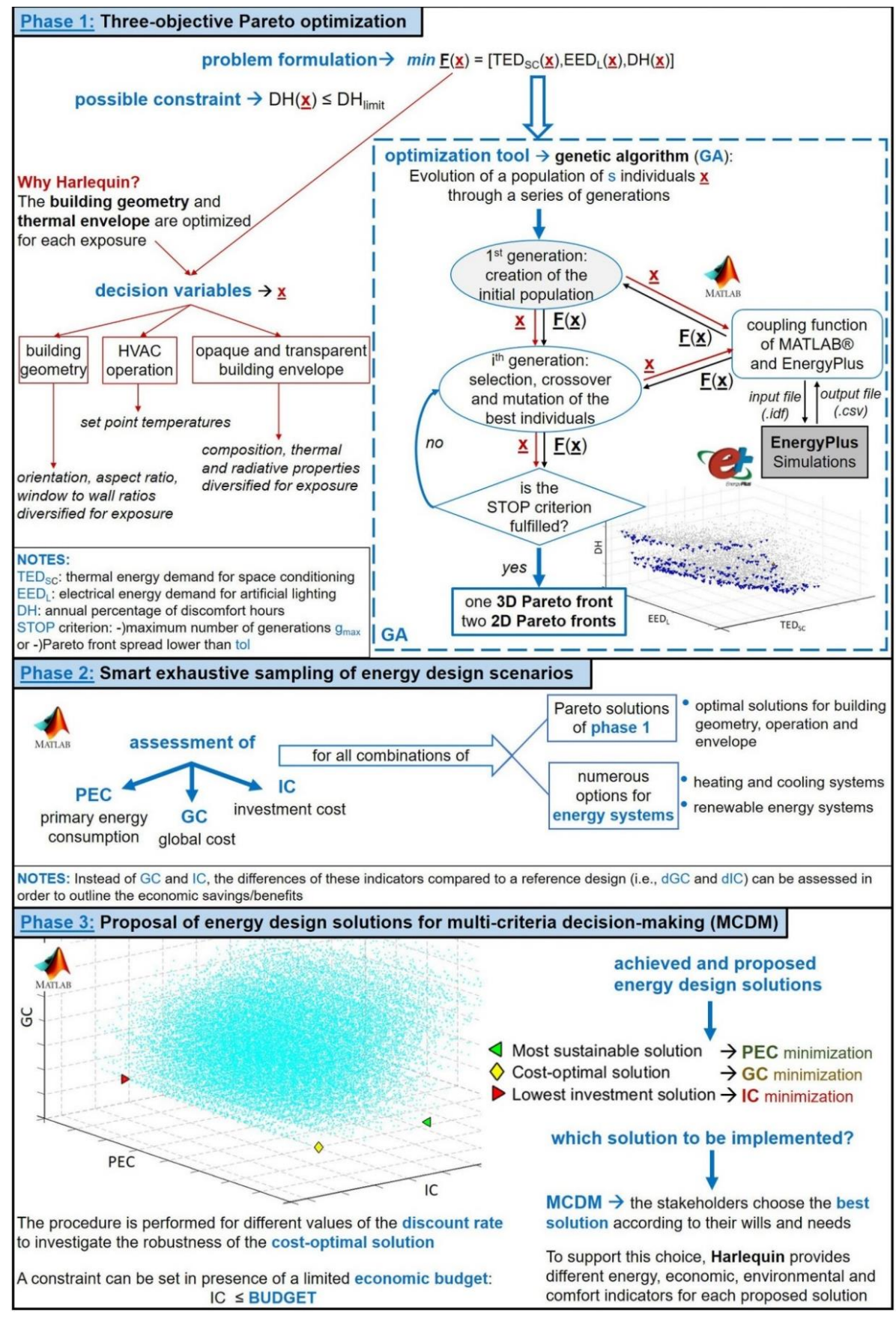

Figure 14. Scheme of the system proposed: Harlequin [83].

In [108], the latest intelligent control systems for energy and comfort control in smart energy buildings were thoroughly and extensively reviewed. [109] represented a simulation model which 
enables the finding of optimal values for different building parameters and the associated effects which decrease the energy demand or consumption of the building.

In [110], the optimization approaches for sustainable building problems were thoroughly examined. The heuristic algorithms widely used to cover direct searches, evolutionary methods, and other organically influenced algorithms are summarized. These algorithms are included GAs [111], EP [112], GP [113], CMA-ES [114], and DE [115]. The main specifications of 74 articles related to the application of mentioned algorithms to various domains of sustainable building design are present in this study.

In [116], the potential of the prefabricated structures for use in new buildings for sustainability, eco-efficiency, and building optimization was discussed, concentrating on the study of a novel dry-dry beam-column relation with various reliability scenarios and re-use scenarios. Additionally, in [117], optimizing building sustainability assessment was presented using building information modeling. In view of criteria for safer and more sustainable buildings, the BSA processes within a BIM framework must be incorporated and streamlined. In [118], an energy optimization was conducted in the various climatic zones of a residential building. In this analysis, the best energy used in a house due to a heating-cooling system was explored through various options under the national code of uniform $R$ values.

In [119], comprehensive agent-based modeling frameworks and methodologies were developed to optimize sustainable building operation in terms of indoor/outdoor thermal comfort and energy consumption levels.

In [120], an optimization model was designed to optimize the efficiency of existing buildings and to test the performance of a proposed project by using a public building in a case study. Reference [121] presents a model of multinational optimization for retrofit planning of buildings with the objective of maximizing energy savings and economic benefits from the given investment budget.

In [122], in order to find an optimal construction envelope design that minimizes life cycle costs and emissions, the multi-objective optimization model based on harmony search algorithms was developed. The pattern has been used in the south of the United States for a typical single-family home. A number of optimal solutions from Pareto solutions were described to help designers better understand the trade relationship between economic and environmental efficiency.

In [123], optimizing the thermal performance of building envelopes for energy consumption saving was performed in office buildings in China for various climates. In [124], multi-objective optimization and the analysis of parametric of a solar heating system were investigated for different building envelopes. In addition, in [125], multi-objective optimization for energy cost management was represented in semi-public buildings using thermal discomfort information.

In [126], evolutionary many-objective optimizations were proposed for retrofit planning in public buildings where NSGA-III resulted in better diversity and where convergence outperforms the conventional NSGA-II. Additionally, [127] integrated distributed generation technologies on sustainable buildings by using multi-objective dimensional method. In their study, objective functions consist of energy generation, total annual cost, emissions generated, and water consumption of the system.

In [128], energy performance of a building, considering different configurations and types of phase change materials, was evaluated by means of multi-objective optimization in five cities of Iran: Tehran, Tabriz, Bandar Abas, Shiraz, and Yazd—each having distinctive climate. In [129], optimization of the HVAC system energy consumption in a building was performed using ANNs and MOGA. The results show that the proposed algorithm has good quality in finding optimum values.

In [130], the MOGA optimization algorithm based on Pareto optimization was applied to the energy design of the building envelope and to minimize primary energy consumption, energy-related global cost, and discomfort hours. Their proposed method was used with four diverse climatic zones in Italy. In [131], also, the MOGA was employed for cost-optimal and low-carbon design of high-rise reinforced concrete buildings. Furthermore, [132] used the improved MOPSO algorithm for campus 
energy plant operation based on building heating load scenarios. Operating costs, system efficiency, and thermal comfort are considered as targets of optimization in their study.

\subsection{Sustainable Environment}

Energy, culture, and living standards are often difficult to describe and are linked in complex ways. Energy choices have influenced cultural and economic development strongly throughout history, as well as living standards. The environmental impact often has an important impact on energy sources and it also impacts society and living standards. The long-term sustainability of the growth of a nation is also impacted by environmental issues.

Due to increased population in the world, living standards, resource use, and industrial activities, the environmental impact of human activities has increased substantially in recent decades. Figure 15 shows the temporal relation between the consumption of energy and the emissions of $\mathrm{CO}_{2}$, where consumption and emissions have similar patterns, showing a strong relationship [47].

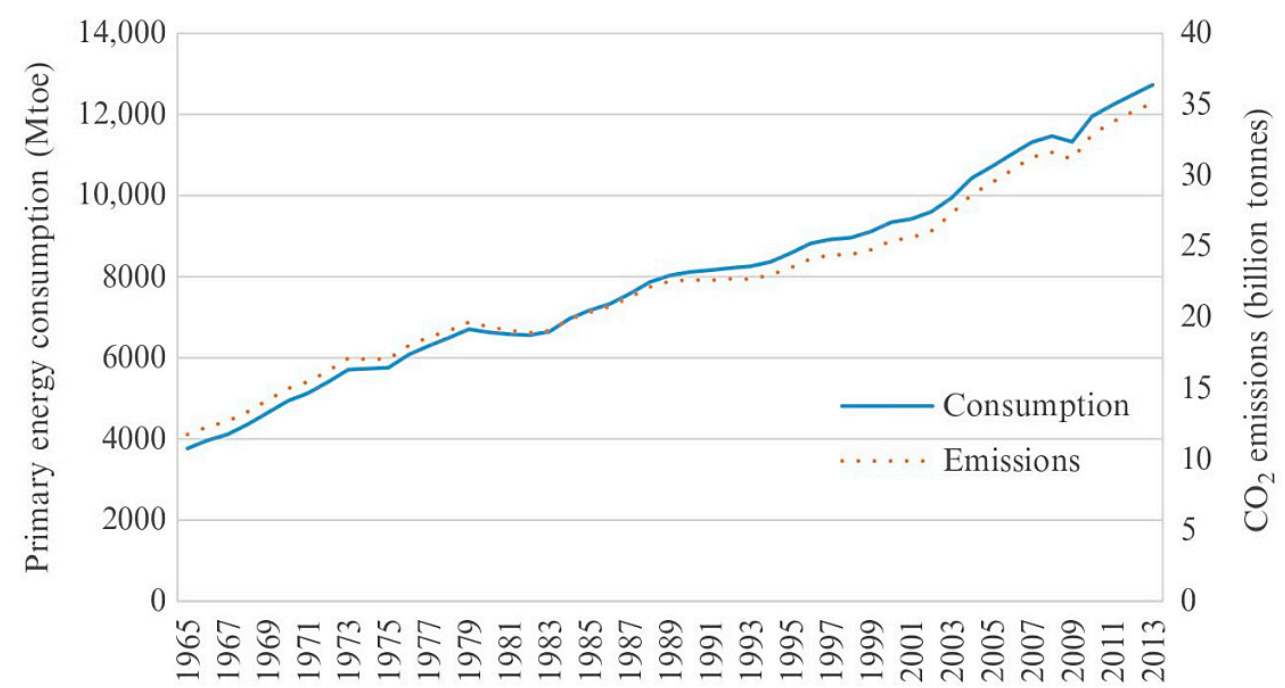

Figure 15. The relation between world consumption of primary energy and $\mathrm{CO}_{2}$ emissions from 1965 to 2013.

Energy-related environmental concerns range from pollutant and accident emissions to environmental degradation and ecosystems. Table 5 provides descriptions of their sources and environmental and human health impacts for several types of pollutants [47].

Table 5. Chosen contaminants and some of their origins and threats.

\begin{tabular}{|c|c|c|}
\hline Pollutant & Source & Risks \\
\hline $\mathrm{CO}$ & Incomplete combustion of fuels & Urban air pollution \\
\hline \multirow[t]{2}{*}{$\mathrm{SO}_{2}$} & Natural processes (e.g., volcanic activity) & $\begin{array}{c}\text { Biological and human health } \\
\text { threats }\end{array}$ \\
\hline & $\begin{array}{l}\text { Sulfur-containing fuels, oil refining, } \\
\text { electricity generation, pulp and paper } \\
\text { industry }\end{array}$ & $\begin{array}{l}\text { Acid precipitation, respiratory } \\
\text { problems }\end{array}$ \\
\hline $\mathrm{NO}_{\mathrm{x}}$ & Combustion of fuels at high temperatures & $\begin{array}{l}\text { Respiratory problems, low-level } \\
\text { ozone formation, creation of acids }\end{array}$ \\
\hline VOCs & Petroleum and solvent vapors & Impede the formation of ozone \\
\hline Particulates (e.g., fly ash) & Natural and anthropogenic sources & Acid precipitation, toxic effects \\
\hline
\end{tabular}


In recent years, industry, the government, and the public have increasingly paid attention to environmental issues, especially as those considerations become an integral part of living standards. Environmental issues therefore also affect culture growth. Energy-related environmental problems have impacted local and regional communities, as well as national and global governments in recent decades (such as climate change and ozone depletion). The main environmental concerns related to power consumption are summarized in Table 6.

Table 6. Summary of major environmental concerns related to energy use and their causes and impacts.

\begin{tabular}{|c|c|c|}
\hline Environmental Concern & Causes & Impacts \\
\hline Global climate change & $\begin{array}{c}\text { Greenhouse gases }\left(\mathrm{CO}_{2}, \mathrm{CH}_{4},\right. \\
\left.\mathrm{CFCs} \text {, halons, } \mathrm{N}_{2} \mathrm{O}\right) \text { emissions, } \\
\text { coal mining, deforestation, general } \\
\text { energy-related activities }\end{array}$ & $\begin{array}{l}\text { Earth surface and sea level increase; coastal } \\
\text { floods; fertile displacement of the area; lack of } \\
\text { freshwater; }\end{array}$ \\
\hline $\begin{array}{c}\text { Stratospheric ozone } \\
\text { depletion }\end{array}$ & CFCs, halons, $\mathrm{N}_{2} \mathrm{O}$ emissions & UV radiation increase (skin cancer, eye damage) \\
\hline Acid precipitation & $\begin{array}{l}\mathrm{SO}_{2}, \mathrm{NO}_{\mathrm{x}}, \mathrm{VOC} \text { emissions, } \\
\text { electricity generation, residential } \\
\text { heating, industrial energy use, } \\
\text { sour gas treatment, transportation }\end{array}$ & $\begin{array}{c}\text { Acidification of lakes, streams, and ground } \\
\text { waters; damage to forests and agricultural crops; } \\
\text { deterioration of materials (buildings, metal } \\
\text { structures, fabrics) }\end{array}$ \\
\hline
\end{tabular}

The following are also additional environmental concerns, many of which have their principal causes and sources listed below [47]:

- Water pollution: Dangerous energy plant and refinery chemicals, mineral acid drainage, geothermal releases of toxic chemicals, and thermal pollution associated with power plant cooling systems releases.

- Maritime pollution: Operations for shipping and accidental oil spills.

- Solid wastes and their disposal: Industries of chemicals, metals, etc.

- Ambient air quality: $\mathrm{SO}_{2}, \mathrm{NO}_{x}, \mathrm{CO}$, VOCs, and particulate matter emissions.

- Hazardous air pollutants: Lead-based fuel additives, emissions from the municipal waste incinerator during oil and gas mining, treatment and combustion, and mercury, chlorinated dioxins, and furans.

- Indoor air quality: $\mathrm{CO}, \mathrm{CO}_{2}$, smoke from stoves and fireplaces, gaseous nitrogen and sulfur oxidizes from furnaces, stray natural gas and oil furnaces, natural gas and soil-burning radon, cigarette smoke and plywood and glues of formaldehyde.

- Land use and siting impact: Refining of fuel, electricity generation, solid waste disposal sites including radioactive waste, hydroelectric reservoirs, mining sites, biomass surface needs, and large-scale renewable energy utilization.

- Radiation and radioactivity: Power (fossil combustion, uranium mining and milling, etc.) processing, decommissioning of nuclear waste, and related substances.

- Major environmental accidents: Fires at refineries, factories, reservoirs and dams, and hydroelectric dam failures causing floods and falls, nuclear accidents, and mining explosions.

There are also optimization approaches for coping with various environmental and ecological problems [133-137].

\section{Discussions}

The combination of "sustainability and optimization" is one of the most important and well-known challenging combinations in today's world. It has attracted considerable attention and insights, especially in recent years. In this regard, the optimal use of resources related to human needs is considered an excellent sustainable goal: environmental, social, and economic goals.

Energy is a key factor for poverty reduction and the improvement of living standards. Energy resources and the dimensions of sustainability need to be integrated together. Thus, some scholars [46] 
also find a strategic dimension related to technological advantages known as sustainability of energy resources in addition to the other three dimensions.

In this review study, more than hundred papers on area of the sustainable energy resources and sustainable buildings were reviewed. It is anticipated that green energy technology will play a crucial role in future sustainable energy environments. Energy demand is likely to be the main factor deciding the role of green energy and technologies. Green electricity from renewable sources including hydraulic energy, solar, wind, geothermal energy, wave, and biomass can be produced to address energy demand.

In the domain of the "optimization and sustainable energy", particularly in the field of energy and building, there are several objectives given in Sections 4.1 and 4.2. In addition, several review papers regarding the state-of-the-art in multi-objective distributed energy resources planning was provided in the recent years.

Buildings worldwide consume a large amount of energy, about one-third of total primary energy supplies. Appropriate energy management in construction has abundant significance to a low carbon world and potentially faster sustainable development under these conditions. Since energy is a principal source and element in building sustainability, and in world sustainable development strategies as well, methods to reduce energy consumption and greenhouse gas emissions in the building sector have been investigated by several sources. Optimization of building energies is an extremely complex process since it involves a broad range of objectives and design variables. Evaluating main characteristics of the reviewed papers on this subject show a growing focus on target functions, particularly in the last decade.

Metaheuristics such as swarm intelligence and evolutionary algorithms are effective for solving energy efficiency problem planning, especially for large-scale and multi-objective problems. However, the analysis demonstrates that the GAs, NSGA-II, PSO and their variants are used more frequently than other optimization algorithms. This is due to the large scope of problems in these papers. In high-dimensional problems, global search-based algorithms are more successful than algorithms that utilize local search strategies such as the TS in finding an optimal solution.

The increasing number of articles published in recent years makes the use of energy efficiency resources for sustainable development and sustainability an interesting subject. Modeling, optimization, and simulation methods have been developed and they have opened new horizons for researchers to use these technologies and instruments for energy resources and energy planning and management. Research and development activities in this sector can now take place.

Using published articles, several research trends and their characteristics can be identified according to the contribution of countries or continents. Optimization targets, single-objective and multi-objective optimization, and optimization algorithms can also be identified.

\subsection{Distribution of Papers to Different Continents}

In Figures 16 and 17, distribution of studied papers are shown with respect to the authors' affiliation to a country or continent. In this regard, Figure 16 indicates distribution of papers based on sustainable energy resources. With respect to the number of research papers, Asia has $54 \%$ of publications in the current research regarding the sustainable energy resources. This development mostly takes place in India $[50,59,62]$ and China $[53,69]$ for understandable reasons. Both countries are emerging and must support their growth and development by looking for renewable and sustainable energy sources. Moreover, China and India contribute approximately $29 \%$ and $7 \%$ of world $\mathrm{CO}_{2}$ emissions combustion in accordance with the statistics of IEA $\left(\mathrm{CO}_{2}\right.$ Emissions from Fuel Combustion, 2019) and are trying to decrease it. 


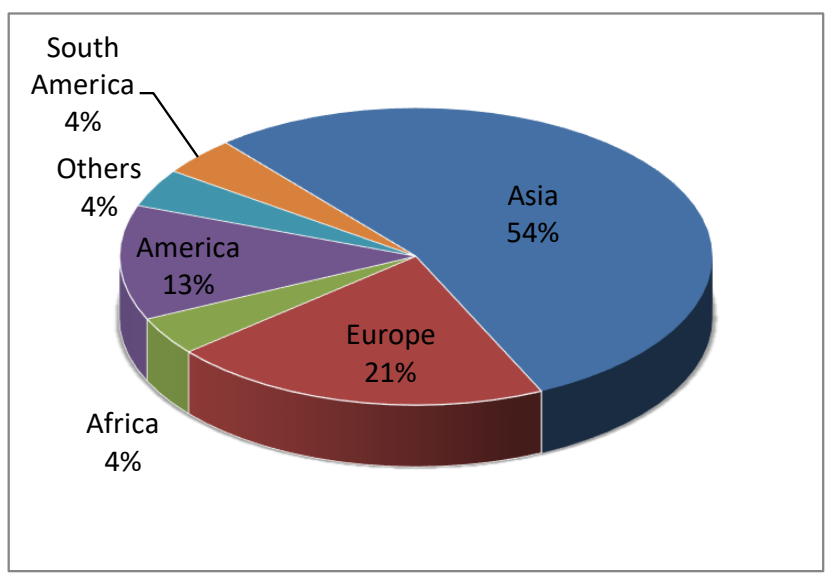

Figure 16. Distribution of papers based on sustainable energy resources to different continents.

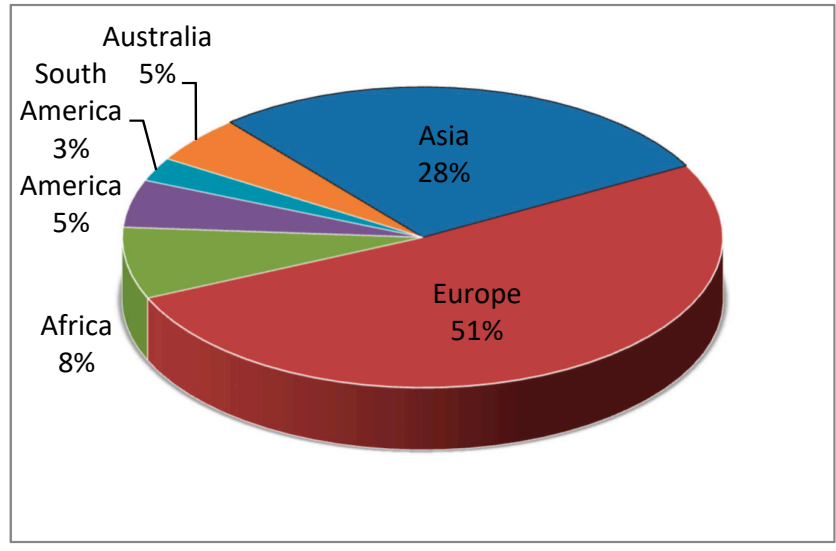

Figure 17. Distribution of papers based on sustainable buildings to different continents.

Figure 17 also depicts distribution of papers based on sustainable buildings in various continents. Due to the number of research papers, Europe has $51 \%$ of publications in the current research related to sustainable buildings. A majority of development in the green continent is related to England $[81,87,91,107,110]$ and Italy $[83,88,93,97,101]$. The presence of advanced building technologies and skills in these countries and the $20 \%$ share of buildings in energy consumption as a significant contribution based on the IEA database have led these countries to have the most research and published articles on optimization of sustainable buildings.

\subsection{Optimization Objectives}

In many articles referenced in this review paper, optimization was performed only to minimize costs. However, due to different economic, social, and other conditions, other goals must also be considered in order to achieve sustainability and sustainable development. In this regard, the study of the reviewed articles shows that in addition to minimizing the energy cost, other energy-related goals have been considered.

In Figure 18, objective functions related to energy are demonstrated, including sustainable energy sources and sustainable buildings. It can be seen from Figure 18 that the share of energy cost is $23 \%$, which is more than other objectives identified in literature. This means that the economic dimension in assessing energy issues remains a top priority. The second, third, and fourth objectives are energy demand with $21 \%$, energy consumption with $17 \%$, and $\mathrm{CO}_{2}$ emissions with $15 \%$. 


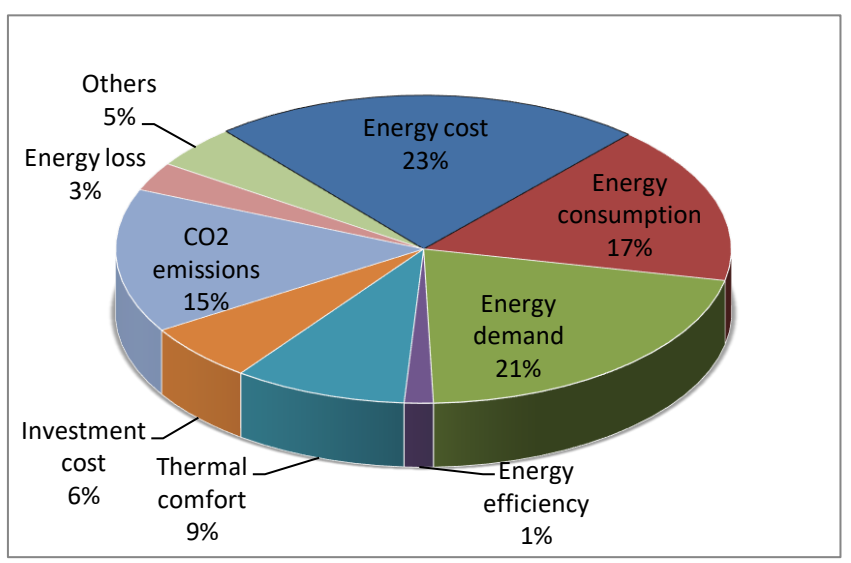

Figure 18. Distribution of objective functions related to energy in reviewed papers.

It appears that optimizing energy consumption and demand in the literature are made in an effort to reduce the pollution caused by energy production. In this regard, many researchers focused on the environmental research related to energy operations, ranging from pollutant emissions and accidents to environmental degradation and ecosystems $[89,91]$. However, to improve energy efficiency, more and more research needs to be performed on energy-related optimization goals and the relationships between them.

\subsection{Single Objective and Multi-Objective Optimization}

Many traditional optimization problems related to energy sustainability in the previous years have been solved without considering the actual dimensions, using only single-objective optimization algorithms. Thus, many publications have considered the targets related to sustainable energy and buildings as a single objective. However, over time and especially in the recent years, the complexity of the issues and the need to consider the actual dimensions and elements, as well as the newness of many optimization objectives, have led researchers and the scientific community to use multi-objective optimization algorithms for optimization in order to optimize and solve sustainability problems precisely. Therefore, the number of papers for the multi-objectives related to sustainable energy and buildings from 2014 to 2019 is much larger than those for a single objective in the reviewed papers (see Figure 19). This suggests the comprehensive evaluation of issues to achieve real and practical optimization should be considered in the form of multi-objective optimization.

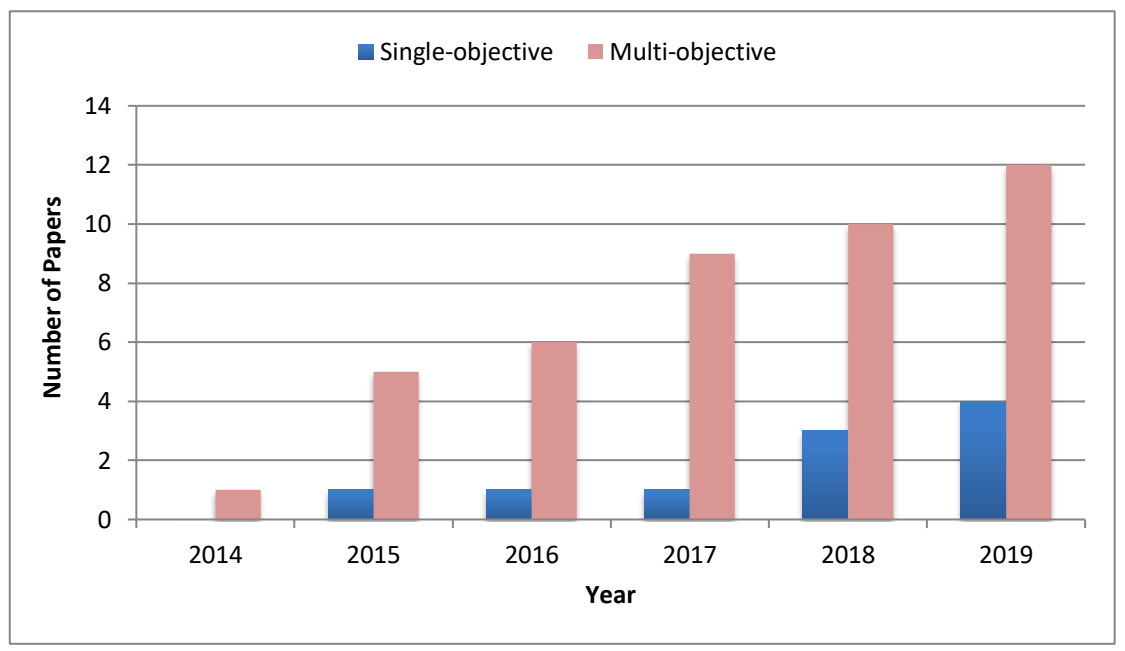

Figure 19. Comparisons of single objective and multi-objective papers by year. 
Flexibility of multi-objective optimization rather than single objective optimization for solving optimization problems, despite several conflicting goals, is another advantage of this approach. Therefore, a desire for solving multi-objective problems led researchers to utilize more exact and complicated processes and patterns based on Pareto front strategy for increasing energy efficiency [28,52,58,122].

\subsection{Optimization Algorithms}

Due to the characteristics and features of problems represented in this review related to sustainable energy resources and sustainable buildings, different and diverse optimization approaches are utilized for solving such problems. Figure 20 displays optimization algorithms used in published articles. In Figure 20, the GAs, NSGA-II, and PSO are the most applicable algorithms for addressing sustainability problems among use optimizers. In this regard, the GAs, NSGA-II, and PSO shares of applied approaches are equal to $25 \%, 17 \%$, and $11 \%$, respectively. Moreover, the total share of GAs and NSGA-II algorithms is about $42 \%$ among all used algorithms. The main reasons of the popularity and efficiency of GAs over other optimizers can be considered as its discrete nature for optimal solving of sustainability problems and being the state-of-the-art algorithm.

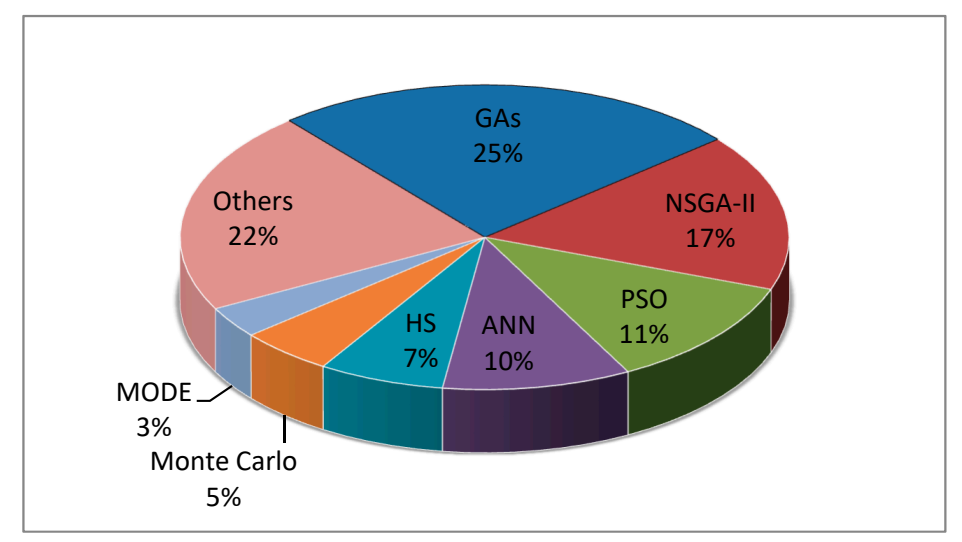

Figure 20. Contribution of optimization algorithms used in the reviewed papers.

\section{Conclusions}

This review paper focuses on relationships between sustainability and optimization methods. The concept and elements of the sustainability have been represented, and the review of the optimization metaheuristic algorithms used in the recent published articles relating to sustainability and sustainable development has been conducted. While studying and analyzing many and various research articles related to the subject from 2014 to present, effort has been made to construct and create a strong understanding of the topic for readers by discussing and summarizing findings found in recent scientific papers. Since energy and energy resources play an important role in sustainable development, in mostly sustainable energy sources, buildings, and environment, these topics are discussed. The results obtained from studies clearly demonstrate the growth in popularity of optimization for the sustainable development including the energy resources and buildings and of multi-objective optimizations in particular. This is partly due to the importance of using the optimization methods to address problems related to the sustainability. Another explanation for the growing interest in optimization is that activists in this field recognize that such approaches have great potential for sustainable development. Additionally, the results of optimizations indicate that energy consumption, power costs, and $\mathrm{CO}_{2}$ emissions are significantly reduced by employing optimization approaches. It is noteworthy that the growth and trend of energy efficiency and deployment of green energies are an interesting and challenging topic relating to sustainability. They are receiving more attention in our society. From the different analyses, the following findings can be summarized: 
- Asia is more focused on sustainable energy resources due to its huge population compared to other continents, while Europe is more focused on sustainable buildings.

- Tendencies of modeling and using multi-objective optimizers compared with single objective models are currently increasing considering more and real objectives inside the optimization model.

- The GAs and other phenomenon-mimicking algorithms are widely used for optimal solutions for sustainable energy resources and sustainable buildings.

Author Contributions: Conceptualization, A.S.; Methodology, A.S.; Software, A.S.; Validation, A.S.; Formal Analysis, A.S.; Writing-Original Draft Preparation, A.S.; Visualization, A.S.; Investigation, M.N.; Resources, M.N.; Data Curation, M.N.; Writing-Review \& Editing, Z.W.G.; Supervision, Z.W.G.; Funding Acquisition, Z.W.G. All authors have read and agreed to the published version of the manuscript.

Funding: This research was supported by the Energy Cloud R\&D Program through the National Research Foundation of Korea (NRF) funded by the Ministry of Science, ICT [2019M3F2A1073164].

Conflicts of Interest: The authors declare no conflict of interest.

\section{Abbreviations}

AFSA

AHP

ANN

ANP-BOCR-DEMATEL-TOPSE

\section{ANP-BOCR-TOPSIS}

ARIMA

BA

BBO

BEO

BIM

BSA

CCHP

CHPED

CMA-ES

$\mathrm{CO}$

DE

DEMATEL

DER

EA

EI

EPA

E-PSO

ES

FPA

GAs

GHGs

GP

GSA

GSO

$\mathrm{HB}$

HC-LSO

HRES

HS
Artificial Fish Swarm Algorithm

Analytic Hierarchy Process

Artificial Neural Networks

Analytic Network Process-Benefits Opportunities Costs Risks-

Decision-Making Trial and Evaluation Laboratory- Technique for

Order of Preference by Similarity to Ideal Solution

Analytic Network Process-Benefits Opportunities Costs Risks-

Technique for Order of Preference by Similarity to Ideal Solution

Autoregressive Integrated Moving Average

Bat Algorithm

Biogeography-Based Optimization

Building Energies Optimization

Building Information Modeling

Building Sustainability Assessment

Combined Cooling, Heating and Power

Combined Heat and Energy Efficiency Dispatch

Covariance Matrix Adaptation Evolutionary Strategy

Carbon monoxide

Differential Evolution

Decision-Making Trial and Evaluation Laboratory

Distributed Energy Resources

Evolutionary Algorithm

Environmental Impact

Environmental Protection Agency

Evolutionary Particle Swarm Optimization

Evolution Strategy

Flower Pollination Algorithm

Genetic Algorithms

Greenhouse Gases

Genetic Programming

Gravitational Search Algorithm

Glow-worm Swarm Optimization

Human Based

Hill Climbing based Local Search Optimization

Hybrid Renewable Energy System

Harmony Search 


\begin{tabular}{|c|c|}
\hline HVAC & Heating, Ventilating and Air Conditioning \\
\hline ICA & Imperialist Competitive Algorithm \\
\hline IEA & International Energy Agency \\
\hline LCO & Life Cycle Optimization \\
\hline MACO & Modified Ant colony optimization \\
\hline MCDM & Multi Criteria Decision Making \\
\hline MILP & Mixed-Integer Linear Programming \\
\hline MINLP & Multi-Objective Nonlinear Mixed-Integer \\
\hline MJAYA & Modified JAYA \\
\hline MODE & Multi-Objective Differential Evolution \\
\hline MOEA & Multi-Objective Evolutionary Algorithm \\
\hline MOGA & Multi-Objective Genetic Algorithm \\
\hline MOOP & Multi-Objective Optimization Problem \\
\hline MOPSO & Mono- and multi-Objective Particle Swarm Optimization \\
\hline NNA & Neural Network Algorithm \\
\hline NOx & Nitrogen Oxides \\
\hline NSGA-II & Non-dominated Sorting Genetic Algorithm II \\
\hline OECD & Organization for Economic Co-operation and Development \\
\hline OPF & Optimal Power Flow \\
\hline PBIL & Population-Based Incremental Learning \\
\hline PCMB & Physics-Chemistry-Math Based \\
\hline PSO & Particle Swarm Optimization \\
\hline PV & Photovoltaic \\
\hline RDGs & Renewable Distributed Generators \\
\hline RE & Renewable Energy \\
\hline SA & Simulated Annealing \\
\hline SI & Swarm Intelligence \\
\hline $\mathrm{SO} 2$ & Sulfur Dioxide \\
\hline SPEA-2 & Strength Pareto Evolutionary Algorithm \\
\hline SRPSO & Self-Regulating Particle Swarm Optimization \\
\hline STRONG & Stochastic Trust-Region Response Surface Method \\
\hline SVRs & Support Vector Regression \\
\hline TLBO & Teaching-Learning Based Optimization \\
\hline TS & Tabu Search \\
\hline TTS & Time-To-Sustainability \\
\hline VCS & Virus Colony Search \\
\hline VOCs & Volatile Organic Compounds \\
\hline WCA & Water Cycle Algorithm \\
\hline
\end{tabular}

\section{References}

1. World Commission on Environment and Development. Our Common Future: Report of the World Commission on Environment and Development; Oxford University Press: Oxford, UK, 1987.

2. Portney, K.E. Sustainability. In Massachusetts Institute of Technology; The MIT Press: Cambridge, UK, 2015.

3. Andrade, J.B.; Bragança, L. Analysis of the impacts of economic and social indicators to sustainability assessment. In Proceedings of the COST C25 International Conference Sustainability of Constructions-Towards a Better Built Environment, Innsbruck, Austria, 3-5 February 2011; pp. 163-168.

4. Glover, F. Tabu search-Part I. Orsa J. Comput. 1989, 1, 190-206. [CrossRef]

5. Sadollah, A.; Eskandar, H.; Kim, J.H. Geometry optimization of a cylindrical fin heat sink using mine blast algorithm. Int. J. Adv. Manuf. Technol. 2014, 73, 795-804. [CrossRef]

6. Lee, H.M.; Yoo, D.G.; Sadollah, A.; Kim, J.H. Optimal cost design of water distribution networks using a decomposition approach. Eng. Optim. 2016, 28, 2141-2156. [CrossRef]

7. Radosavljević, J. Metaheuristic Optimization in Power Engineering; The Institution of Engineering and Technology Press: London, UK, 2018. 
8. Fister, I., Jr.; Yang, X.-S.; Fister, I.; Brest, J.; Fister, D. A brief review of nature-inspired algorithms for optimisation. ElektrotehVestn 2013, 80, 1-7.

9. Yang, X.S. Nature-Inspired Metaheuristic Algorithms, 2nd ed.; Luniver Press: Luniver, UK, 2010.

10. Fausto, F.; Reyna-Orta, A.; Cuevas, E.; Andrade, Á.G.; Perez-Cisneros, M. From ants to whales: Metaheuristics for all tastes. Artif. Intell. Rev. 2020, 53, 753-810. [CrossRef]

11. He, D.-X.; Liu, G.-Q.; Zhu, H.-Z. Glowworm Swarm Optimization Algorithm for Solving Multi-objective Optimization Problem. In Proceedings of the 9th International Conference on Computational Intelligence and Security, IEEE, Leshan, China, 14-15 December 2013. [CrossRef]

12. Sanseverino, E.R.; Nguyen, N.Q.; di Silvestre, M.L.; Zizzo, G.; de Bosio, F.; Tran, Q.T.T. Frequency constrained optimal power flow based on glow-worm swarm optimization in islanded microgrids. In Proceedings of the 2015 AEIT International Annual Conference (AEIT), IEEE, Naples, Italy, 14-16 October 2015. [CrossRef]

13. Holland, J. Adaptation in Natural and Artificial Systems; University of Michigan Press: Ann Arbor, MI, USA, 1975.

14. Kennedy, J.; Eberhart, R. Particle swarm optimization. In Proceedings of the 1995 IEEE International Conference on Neural Networks, Perth, Australia, 27 November-1 December 1995; pp. 1942-1948.

15. Rao, R.V.; Savsani, V.J.; Vakharia, D. Teaching-learning-based optimization: A novel method for constrained mechanical design optimization problems. Comput. Aided Des. 2011, 43, 303-315. [CrossRef]

16. Geem, Z.W.; Kim, J.H.; Loganathan, G.V. A new heuristic optimization algorithm: Harmony search. Simulation 2001, 76, 60-68. [CrossRef]

17. Eskandar, H.; Sadollah, A.; Bahreininejad, A.; Hamdi, M. Water cycle algorithm-A novel metaheuristic optimization method for solving constrained engineering optimization problems. Comput. Struct. 2012, 110-111, 151-166. [CrossRef]

18. Abu-Rayash, A.; Dincer, I. Sustainability Assessment of Energy Systems: A Novel Integrated Model. J. Clean. Prod. 2018, 212, 1098-1116. [CrossRef]

19. Bhinge, R.; Moser, R.; Moser, E.; Lanza, G.; Dornfeld, D. Sustainability Optimization for Global Supply Chain Decision-making. Procedia CIRP 2015, 26, 323-328. [CrossRef]

20. Al-Sharrah, G.; Elkamel, A.; Almanssoor, A. Sustainability indicators for decision-making and optimization in the process industry: The case of the petrochemical industry. Chem. Eng. Sci. 2010, 65, 1452-1461. [CrossRef]

21. Liu, Z.; Huang, Y. Sustainability enhancement under uncertainty: A Monte Carlo-based simulation and system optimization method. Clean Technol. Environ. Policy 2015, 17, 1757-1768. [CrossRef]

22. Tapia, C.; Padgett, J.E. Multi-objective optimization of bridge retrofit and post-event repair selection to enhance sustainability. Struct. Infrastruct. Eng. 2016, 12, 93-107. [CrossRef]

23. Pratama, Y.W.; Purwanto, W.W.; Tezuka, T.; McLellan, B.C.; Hartono, D.; Hidayatno, A.; Daud, Y. Multiobjective optimization of a multiregional electricity system in an archipelagic state: The role of renewable energy in energy system sustainability. Renew. Sustain. Energy Rev. 2017, 77, 423-439. [CrossRef]

24. Lee, S.; Esfahani, I.J.; Ifaei, P.; Moya, W.; Yoo, C.K. Thermo-environ-economic modeling and optimization of an integrated wastewater treatment plant with a combined heat and power generation system. Energy Convers. Manag. 2017, 142, 385-401. [CrossRef]

25. Sekimoto, H.; Nagata, A. Performance optimization of the CANDLE reactor for nuclear energy sustainability. Energy Convers. Manag. 2010, 51, 1788-1791. [CrossRef]

26. Jawahar, N.; SatishPandian, G.; Gunasekaran, A.; Subramanian, N. An Optimization Model for Sustainability Program. Ann. Oper. Res. 2017, 250, 389-425. [CrossRef]

27. Kannegiesser, M.; Günther, H.O.; Autenrieb, N. The time-to-sustainability optimization strategy for sustainable supply network design. J. Clean. Prod. 2015, 108, 451-463. [CrossRef]

28. Meng, K.; Lou, P.; Peng, X.; Prybutok, V. Multi-objective optimization decision-making of quality dependent product recovery for sustainability. Int. J. Prod. Econ. 2017, 188, 72-85. [CrossRef]

29. Brown, B.J.; Hanson, M.E.; Liverman, D.M.; Meredith, R.W. Global Sustainability: Toward Definition. Environ. Manag. 1987, 11, 713-719. [CrossRef]

30. Osman, I.H.; Laporte, G. Metaheuristics: A bibliography. Ann. Oper. Res. 1996, 63, 513-623. [CrossRef]

31. Yang, X.S. Engineering Optimization: An Introduction with Metaheuristic Applications; John Wiley \& Sons: Hoboken, NJ, USA, 2010. 
32. Glover, F.; Kochenberger, G.A. Handbook of Metaheuristics; Kluwer Academic Publishers: New York, NY, USA, 2003.

33. Saka, M.P.; Hasançebi, O.; Geem, Z.W. Metaheuristics in Structural Optimization and Discussions on Harmony Search Algorithm. Swarm Evol. Comput. 2016, 28, 88-97.

34. Price, K.V.; Storn, R.M.; Lampinen, J.A. Differential evolution. In A Practical Approach to Global Optimization; Springer: Berlin, Germany, 2005.

35. Simon, D. Biogeography-Based Optimization. IEEE Trans. Evol. Comput. 2008, 12, 702-713. [CrossRef]

36. Rechenberg, I. Evolutions Strategy; Springer: Berlin/Heidelberg, Germany, 1978; pp. 83-114.

37. Dasgupta, D.; Michalewicz, Z. Evolutionary Algorithms in Engineering Applications; Springer Science 781 \& Business Media: Berlin, Germany, 1997.

38. Koza, J.R. Genetic Programming: On the Programming of Computers by Means of Natural Selection; MIT Press: Cambridge, MA, USA, 1992.

39. Li, M.D.; Zhao, H.; Weng, X.W.; Han, T. A novel nature-inspired algorithm for optimization: Virus colony search. Adv. Eng. Softw. 2016, 92, 65-88. [CrossRef]

40. Sadollah, A.; Sayyaadi, H.; Yadav, A. A dynamic metaheuristic optimization model inspired by biological nervous systems: Neural network algorithm. Appl. Soft Comput. 2018, 71,747-782. [CrossRef]

41. Martens, P. Sustainability: Science or fiction? Sci. Pract. Policy 2006, 2, 36-41. [CrossRef]

42. Hueting, R.; Reijnders, L. Broad sustainability contra sustainability: The proper construction of sustainability indicators. Ecol. Econ. 2004, 50, 249-260. [CrossRef]

43. Liberti, L. Optimization and sustainable development. Comput. Manag. Sci. 2015, 12, 371-395. [CrossRef]

44. Hopwood, B.; Mellor, M.; O’Brien, G. Sustainable Development: Mapping Different Approaches. Sustain. Dev. 2005, 13, 38-52. [CrossRef]

45. Poole, M.S.; Van de Ven, A.H. Handbook of Organizational Change and Innovation; Oxford University Press: New York, NY, USA, 2004.

46. Dincer, I.; Zamfirescu, C. Sustainability Dimensions of Energy. Compr. Energy Syst. 2018, 1, 101-152.

47. Dincer, I.; Rosen, M.A. Chapter 1-Exergy and Its Ties to the Environment, Economics, and Sustainability. In Exergy Analysis of Heating, Refrigerating and Air Conditioning; Ibrahim, D., Rosen, M.A., Eds.; Elsevier: Amsterdam, The Netherlands, 2015; pp. 1-42.

48. Elattar, E.E.; ElSayed, S.K. Modified JAYA algorithm for optimal power flow incorporating renewable energy sources considering the cost, emission, power loss and voltage profile improvement. Energy 2019, 178, 598-609. [CrossRef]

49. Kumar, K.P.; Saravanan, B.; Swarup, K.S. Optimization of Renewable Energy Sources in a Microgrid Using Artificial Fish Swarm Algorithm. Energy Procedia 2016, 90, 107-113. [CrossRef]

50. Lorestani, A.; Ardehali, M.M. Optimal integration of renewable energy sources for autonomous tri-generation combined cooling, heating and power system based on evolutionary particle swarm optimization algorithm. Energy 2018, 145, 839-855. [CrossRef]

51. Gómez, C.; Jiménez-Fernández, S.; Mallol-Poyato, R. Optimal design of Microgrid's network topology and location of the distributed renewable energy resources using the Harmony Search algorithm. Soft Comput. 2019, 23, 6495. [CrossRef]

52. Dhunny, A.Z.; Allam, Z.; Lobine, D.; Lollchund, M.R. Sustainable renewable energy planning and wind farming optimization from a biodiversity perspective. Energy 2019, 185, 1282-1297. [CrossRef]

53. Purwanto, W.W.; Pratama, Y.W.; Nugroho, Y.S.; Warjito; Hertono, G.F.; Hartono, D.; Deendarlianto; Tezuka, T. Multi-objective optimization model for sustainable Indonesian electricity system: Analysis of economic, environment, and adequacy of energy sources. Renew. Energy 2015, 81, 308-318.

54. Majewski, D.E.; Wirtz, M.; Lampe, M.; Bardow, A. Robust multi-objective optimization for sustainable design of distributed energy supply systems. Comput. Chem. Eng. 2017, 102, 26-39. [CrossRef]

55. Selvam, P.P.; Narayanan, R. Random restart local search optimization technique for sustainable energy-generating induction machine. Comput. Electr. Eng. 2019, 73, 268-278. [CrossRef]

56. Aviso, K.B.; Lee, J.-Y.; Dulatre, J.C.; Madria, V.R.; Okusa, J.; Tan, R. A P-graph model for multi-period optimization of sustainable energy systems. J. Clean. Prod. 2017, 161, 1338-1351. [CrossRef]

57. Tuttle, J.F.; Vesel, R.; Alagarsamy, S.; Blackburn, L.D.; Powell, K. Sustainable NOx emission reduction at a coal-fired power station through the use of online neural network modeling and particle swarm optimization. Control Eng. Pract. 2019, 93, 104167. [CrossRef] 
58. Chang, K.; Lin, G. Optimal design of hybrid renewable energy systems using simulation optimization. Simul. Model. Pract. Theory 2015, 52, 40-51. [CrossRef]

59. Lashkar Ara, A.; Mohammad Shahi, N.; Nasir, M. CHP Economic Dispatch Considering Prohibited Zones to Sustainable Energy Using Self-Regulating Particle Swarm Optimization Algorithm. Iran. J. Sci. Technol. Trans. Electr. Eng. 2019, 1-18. [CrossRef]

60. Ibrahim, A.M.; Swief, R.A. Comparison of modern heuristic algorithms for loss reduction in power distribution network equipped with renewable energy resources. Ain Shams Eng. J. 2018, 9, 3347-3358. [CrossRef]

61. Liu, J.; Yin, Y. An integrated method for sustainable energy storing node optimization selection in China. Energy Convers. Manag. 2019, 199, 112049. [CrossRef]

62. Siala, K.; de la Rúa, C.; Lechón, Y.; Hamacher, T. Towards a sustainable European energy system: Linking optimization models with multi-regional input-output analysis. Energy Strategy Rev. 2019, 26, 100391. [CrossRef]

63. Gong, J.; You, F. Sustainable Design of Energy Systems by Integrating Life Cycle Optimization with Superstructure Optimization. In Computer Aided Chemical Engineering; Muñoz, S.G., Laird, C.D., Realff, M.J., Eds.; Elsevier: Amsterdam, The Netherlands, 2019; Volume 47, pp. 211-220.

64. Wagh, M.M.; Kulkarni, V.V. Modeling and Optimization of Integration of Renewable Energy Resources (RER) for Minimum Energy Cost, Minimum CO2 Emissions and Sustainable Development, in Recent Years: A Review. Mater. Today Proc. 2018, 5, 11-21. [CrossRef]

65. Baños, R.; Manzano-Agugliaro, F.; Montoya, F.G.; Gil, C.; Alcayde, A.; Gómez, J. Optimization methods applied to renewable and sustainable energy: A review. Renew. Sustain. Energy Rev. 2011, 15, 1753-1766. [CrossRef]

66. Bazmi, A.A.; Zahedi, G. Sustainable energy systems: Role of optimization modeling techniques in power generation and supply-A review. Renew. Sustain. Energy Rev. 2011, 15, 3480-3500. [CrossRef]

67. Luna-Rubio, R.; Trejo-Perea, M.; Vargas-Vazquez, D.; Ros-Moreno, G.J. Optimal sizing of renewable hybrids energy systems: A review of methodologies. Sol. Energy 2012, 86, 1077-1088. [CrossRef]

68. Tozzi, P.; Jo, J.H. A comparative analysis of renewable energy simulation tools: Performance simulation model vs. system optimization. Renew. Sustain. Energy Rev. 2017, 80, 390-398. [CrossRef]

69. Alarcon-Rodriguez, A.; Ault, G.; Galloway, S. Multi-objective planning of distributed energy resources: A review of the state-of-the-art. Renew. Sustain. Energy Rev. 2010, 14, 1353-1366. [CrossRef]

70. Gao, K.; Huang, Y.; Sadollah, A.; Wang, L. A review of energy-efficient scheduling in intelligent production systems. Complex Intell. Syst. 2019. [CrossRef]

71. Nazari-Heris, M.; Mohammadi-Ivatloo, B.; Asadi, S.; Kim, J.-H.; Geem, Z.W. Harmony Search Algorithm for Energy System Applications: An Updated Review and Analysis. J. Exp. Theor. Artif. Intell. 2019, 31, 723-749. [CrossRef]

72. Hill, R.; Bowen, P. Sustainable construction: Principles and a framework. Constr. Manag. Econ. 1997, 15, 223-239. [CrossRef]

73. Lowe, R. Addressing the challenges of climate change for the built environment. Build. Res. Inf. 2007, 35, 343-350. [CrossRef]

74. Kibert, C.J. The next generation of sustainable construction. Build. Res. Inf. 2007, 35, 595-601. [CrossRef]

75. Cassidy, R. White Paper on Sustainability. Building Design and Construction, 11. Available online: http://www.usgbc.org/Docs/Resources/BDCWhitePaperR2.pdf (accessed on 12 December 2019).

76. Environmental Protection Agency. Green Building Strategy—Defines Green Building and Explains EPA's Strategic Role in Facilitating the Mainstream Adoption of Effective Green Building Practices; EPA: Washington, DC, USA, 2008.

77. Berardi, U. Moving to Sustainable Buildings: Paths to Adopt Green Innovations in Developed Countries; Walter de Gruyter: Berlin, Germany, 2013.

78. Longo Francesco Montana, S.; Sanseverino, E.R. A Review on Optimization and Cost-Optimal Methodologies in Low-Energy Buildings Design and Environmental Considerations. Sustain. Cities Soc. 2019, 45, 87-104. [CrossRef]

79. Waibel, C.; Wortmann, T.; Evins, R.; Carmeliet, J. Building energy optimization: An extensive benchmark of global search algorithms. Energy Build. 2019, 187, 218-240. [CrossRef] 
80. Vincent, J.L.; Gan, H.K.; Wong, K.T.; Tse, J.C.P.; Cheng, I.M.C.; Lo, C.M.C. Simulation-based evolutionary optimization for energy-efficient layout plan design of high-rise residential buildings. J. Clean. Prod. 2019, $231,1375-1388$.

81. Goudarzi, S.; Anisi, M.H.; Kama, N.; Doctor, F.; Soleymani, S.A.; Sangaiah, A.K. Predictive modelling of building energy consumption based on a hybrid nature-inspired optimization algorithm. Energy Build. 2018, 196, 83-93. [CrossRef]

82. Li, H.; Wang, S. Coordinated optimal design of zero/low energy buildings and their energy systems based on multi-stage design optimization. Energy 2019, 189, 116202. [CrossRef]

83. Ascione, F.; Bianco, N.; Mauro, G.M.; Vanoli, G.P. A new comprehensive framework for the multi-objective optimization of building energy design: Harlequin. Appl. Energy 2019, 241, 331-361. [CrossRef]

84. Jain, A.S.; Saikia, P.; Rakshit, D. Thermal Energy Performance of an Academic Building with Sustainable Probing and Optimization with Evolutionary Algorithm. Therm. Sci. Eng. Prog. 2020, 17, 100374. [CrossRef]

85. Bamdad, K.; Cholette, M.E.; Guan, L.; Bell, J. Building energy optimization under uncertainty using ACOMV algorithm. Energy Build. 2018, 167, 322-333. [CrossRef]

86. Gou, S.; Nik, V.M.; Scartezzini, J.L.; Zhao, Q.; Li, Z. Passive design optimization of newly-built residential buildings in Shanghai for improving indoor thermal comfort while reducing building energy demand. Energy Build. 2018, 169, 484-506. [CrossRef]

87. Reynolds, J.; Rezgui, Y.; Kwan, A.; Piriou, S. A zone-level, building energy optimization combining an artificial neural network, a genetic algorithm, and model predictive control. Energy 2018, 151, 729-739. [CrossRef]

88. Smarra, F.; Jain, A.; de Rubeis, T.; Ambrosini, D.; D’Innocenzo, A.; Mangharam, R. Data-driven model predictive control using random forests for building energy optimization and climate control. Appl. Energy 2018, 224, 147-159. [CrossRef]

89. Li, K.; Pan, L.; Xue, W.; Jang, H.; Hanping, M. Multi-objective optimization for energy performance improvement of residential buildings: A comparative study. Energies 2017, 10, 245. [CrossRef]

90. Fan, Y.; Xia, X. A multi-objective optimization model for energy-efficiency building envelope retrofitting plan with rooftop PV system installation and maintenance. Appl. Energy 2017, 189, 327-335. [CrossRef]

91. Galvez, D.M.; Kerdan, I.G.; Raslan, R.; Ruyssevelt, P. ExRET-Opt: An automated exergy/exergoeconomic simulation framework for building energy retrofit analysis and design optimization. Appl. Energy 2017, 192, 33-58.

92. Mostavi, E.; Asadi, S.; Boussaa, D. Development of a new methodology to optimize building life cycle cost, environmental impacts, and occupant satisfaction. Energy 2017, 121, 606-615. [CrossRef]

93. Salata, F.; Golasi, I.; Domestico, U.; Banditelli, M.; Lo Basso, G.; Nastasi, B.; Vollaro, A.L. Heading towards the nZEB through $\mathrm{CHP}+\mathrm{HP}$ systems. A comparison between retrofit solutions able to increase the energy performance for the heating and domestic hot water production in residential buildings. Energy Convers. Manag. 2017, 138, 61-76. [CrossRef]

94. Wu, R.; Mavromatidis, G.; Orehounig, G.; Carmeliet, J. Multi-objective optimization of energy systems and building envelope retrofit in a residential community. Appl. Energy 2017, 190, 434-649. [CrossRef]

95. Yang, M.D.; Lin, M.D.; Lin, Y.H.; Tsai, K.T. Multi-objective optimization design of green building envelope material using a non-dominated sorting genetic algorithm. Appl. Therm. Eng. 2017, 111, 1255-1264. [CrossRef]

96. Zhang, A.; Bokel, R.; van den Dobbelsteen, A.; Sun, Y.; Huang, Q.; Zhang, Q. Optimization of thermal and daylight performance of school buildings based on a multi-objective genetic algorithm in the cold climate of China. Energy Build. 2017, 139, 371-384. [CrossRef]

97. Ascione, F.; Bianco, N.; De Masi, R.F.; Mauro, G.M.; Vanoli, G.P. Resilience of robust costoptimal energy retrofit of buildings to global warming: A multi-stage, multi-objective approach. Energy Build. 2017, 153, 150-167. [CrossRef]

98. Folic, R.; Harmathy, N.; Magyar, Z. Multi-criteria optimization of building envelope in the function of indoor illumination quality towards overall energy performance improvement. Energy 2016, 114, 302-317.

99. Bre, F.; Santos Silva, A.; Ghisi, E.; Fachinotti, V.D. Residential building design optimization using sensitivity analysis and genetic algorithm. Energy Build. 2016, 133, 853-866. [CrossRef] 
100. Delgarm, N.; Sajadi, B.; Delgarm, S.; Kowsari, F. A novel approach for the simulationbased optimization of the buildings energy consumption using NSGA-II: Case study in Iran. Energy Build. 2016, 127, 552-560. [CrossRef]

101. Brunelli, C.; Castellani, F.; Garinei, A.; Biondi, L.; Marconi, M. A procedure to perform multi-objective optimization for sustainable design of buildings. Energies 2016, 9, 915. [CrossRef]

102. Delgarm, N.; Sajadi, B.; Kowsary, F.; Delgarm, S. Multi-objective optimization of the building energy performance: A simulation-based approach by means of particle swarm optimization (PSO). Appl. Energy 2016, 170, 293-303. [CrossRef]

103. Kong, D.S.; Jang, Y.S.; Huh, G.H. Method and case study of multi-objective optimization based energy system design to minimize the primary energy use and initial investment cost. Energies 2015, 8, 6114-6134. [CrossRef]

104. Evins, R. Multi-level optimization of building design, energy system sizing and operation. Energy 2015, 90, 1775-1789. [CrossRef]

105. Asadi, E.; Gameiro da Silva, M.; Antunes, C.H.; Dias, L.; Glicksman, L. Multi-objective optimization for building retrofit: A model using genetic algorithm and artificial neural network and an application. Energy Build. 2014, 81, 444-456. [CrossRef]

106. Hamdy, M.; Nguyen, A.T.; Hensen, J.L.M. A Performance Comparison of Multi-Objective Optimization Algorithms for Solving Nearly-Zero-Energy-Building Design Problems. Energy Build. 2016, 121, 57-71. [CrossRef]

107. Karmellos, M.; Kiprakis, A.; Mavrotas, G. A multi-objective approach for optimal prioritization of energy efficiency measures in buildings: Model, software and case studies. Appl. Energy 2015, 139, 131-150. [CrossRef]

108. Shaikh, P.H.; Nor, N.B.M.; Nallagownden, P.; Elamvazuthi, I.; Ibrahim, T. A review on optimized control systems for building energy and comfort management of smart sustainable buildings. Renew. Sustain. Energy Rev. 2014, 34, 409-429. [CrossRef]

109. Casas, P.F.I.; Casas, A.F.I.; Garrido-Soriano, N.; Casanovas, J. Formal simulation model to optimize building sustainability. Adv. Eng. Softw. 2014, 69, 62-74. [CrossRef]

110. Evins, R. A review of computational optimization methods applied to sustainable building design. Renew. Sustain. Energy Rev. 2013, 22, 230-245. [CrossRef]

111. Goldberg, D.E. Genetic Algorithms in Search, Optimization, and Machine Learning, 1st ed.; Addison-Wesley Professional: Boston, MA, USA, 1989.

112. Fogel, L.J. Intelligence through Simulated Evolution: Forty Years of Evolutionary Programming; Wiley-Blackwell: Hoboken, NJ, USA, 1999.

113. Sette, S.; Boullart, L. Genetic programming: Principles and applications. Eng. Appl. Artif. Intell. 2001, 14, 727-736. [CrossRef]

114. Hansen, N.; Ostermeier, A. Adapting arbitrary normal mutation distributions in evolution strategies: The covariance matrix adaptation. In Proceedings of the IEEE International Conference on Evolutionary Computation, Nagoya, Japan, 20-22 May 1996; pp. 312-317.

115. Storn, R.; Price, K. Differential evolution a simple and efficient heuristic for global optimization over continuous spaces. J. Glob. Optim. 1997, 11, 341-359. [CrossRef]

116. Navarro-Rubio, J.; Pineda, P.; García-Martínez, A. Sustainability, prefabrication and building optimization under different durability and re-using scenarios: Potential of dry precast structural connections. Sustain. Cities Soc. 2019, 44, 614-628. [CrossRef]

117. Carvalho, J.P.; Bragança, L.; Mateus, R. Optimizing building sustainability assessment using BIM. Autom. Constr. 2019, 102, 170-182. [CrossRef]

118. Tushar, Q.; Bhuiyan, M.; Sandanayake, M.; Zhang, G. Optimizing the energy consumption in a residential building at different climate zones: Towards sustainable decision making. J. Clean. Prod. 2019, 233, 634-649. [CrossRef]

119. Azar, E.; Nikolopoulou, C.; Papadopoulos, S. Integrating and optimizing metrics of sustainable building performance using human-focused agent-based modeling. Appl. Energy 2016, 183, 926-937. [CrossRef]

120. Abdallah, M.; El Rayes, K. Multiobjective Optimization Model for Maximizing Sustainability of Existing Buildings. J. Manag. Eng. 2016, 32. [CrossRef] 
121. Fan, Y.; Xia, X. A Multi-objective Optimization Model for Building Envelope Retrofit Planning. Energy Procedia 2015, 75, 1299-1304. [CrossRef]

122. Fesanghary, M.; Asadi, S.; Geem, Z.W. Design of Low-Emission and Energy-Efficient Residential Buildings Using a Multi-Objective Optimization Algorithm. Build. Environ. 2012, 49, 245-250. [CrossRef]

123. Shi, L.; Zhang, H.; Li, Z.; Luo, Z.; Liu, J. Optimizing the thermal performance of building envelopes for energy saving in underground office buildings in various climates of China. Tunn. Undergr. Space Technol. 2018, 77, 26-35. [CrossRef]

124. Mitsopoulos, G.; Bellos, E.; Tzivanidis, C. Parametric analysis and multi-objective optimization of a solar heating system for various building envelopes. Therm. Sci. Eng. Prog. 2018, 8, 307-317. [CrossRef]

125. Gaonkar, P.; Bapat, J.; Das, D. Location-aware multi-objective optimization for energy cost management in semi-public buildings using thermal discomfort information. Sustain. Cities Soc. 2018, 40, 174-181. [CrossRef]

126. Son, H.; Kim, C. Evolutionary many-objective optimization for retrofit planning in public buildings: A comparative study. J. Clean. Prod. 2018, 190, 403-410. [CrossRef]

127. Fuentes-Cortés, L.F.; Flores-Tlacuahuac, A. Integration of distributed generation technologies on sustainable buildings. Appl. Energy 2018, 224, 582-601. [CrossRef]

128. Markarian, E.; Fazelpour, F. Multi-objective optimization of energy performance of a building considering different configurations and types of PCM. Sol. Energy 2019, 191, 481-496. [CrossRef]

129. Nasruddin, N.; Sholahudin, S.; Satrio, P.; Mahlia, T.M.I.; Giannetti, N.; Saito, K. Optimization of HVAC system energy consumption in a building using artificial neural network and multi-objective genetic algorithm. Sustain. Energy Technol. Assess. 2019, 35, 48-57. [CrossRef]

130. Ascione, F.; Bianco, N.; Mauro, G.M.; Napolitano, D.F. Building envelope design: Multi-objective optimization to minimize energy consumption, global cost and thermal discomfort. Application to different Italian climatic zones. Energy 2019, 174, 359-374. [CrossRef]

131. Vincent, J.L.; Gan, C.L.; Wong, K.T.; Tse, J.C.P.; Cheng, I.M.C.; Lo, C.M.C. Parametric modelling and evolutionary optimization for cost-optimal and low-carbon design of high-rise reinforced concrete buildings. Adv. Eng. Inform. 2019, 42. [CrossRef]

132. Ding, Y.; Wang, Q.; Kong, X.; Yang, K. Multi-objective optimisation approach for campus energy plant operation based on building heating load scenarios. Appl. Energy 2019, 250, 1600-1617. [CrossRef]

133. Geem, Z.W.; Chung, S.Y.; Kim, J.-H. Improved Optimization for Wastewater Treatment and Reuse System using Computational Intelligence. Complexity 2018. Article ID 2480365. [CrossRef]

134. Geem, Z.W.; Kim, J.-H. Sustainable Optimization for Wastewater Treatment System Using PSF-HS. Sustainability 2016, 8, 321. [CrossRef]

135. Geem, Z.W.; Kim, J.H. Wastewater Treatment Optimization for Fish Migration Using Harmony Search. Math. Probl. Eng. 2014. Article ID 313157. [CrossRef]

136. Geem, Z.W. Can Music Supplant Math in Environmental Planning? Leonardo 2015, 48, 147-150. [CrossRef]

137. Geem, Z.W.; Williams, J.C. Harmony Search and Ecological Optimization. Int. J. Energy Environ. 2007, 1, 150-154.

(C) 2020 by the authors. Licensee MDPI, Basel, Switzerland. This article is an open access article distributed under the terms and conditions of the Creative Commons Attribution (CC BY) license (http://creativecommons.org/licenses/by/4.0/). 